\title{
МИНЕРАЛЬНО-СЫРЬЕВАЯ БАЗА НЕМЕТАЛЛИЧЕСКИХ ПОЛЕЗНЫХ ИСКОПАЕМЫХ ЦЕНТРАЛЬНО-ЧЕРНОЗЕМНОГО РЕГИОНА И РАЦИОНАЛЬНОЕ ЕЁ ИСПОЛЬЗОВАНИЕ. СТАТЬЯ 2. МОДЕЛЬ РАЦИОНАЛЬНОГО ИСПОЛЬЗОВАНИЯ МИНЕРАЛЬНО-СЫРЬЕВОЙ БАЗЫ НЕМЕТАЛЛОВ
}

\author{
Д. А. Дмитриев, А. Д. Савко, С. А. Куролап, В. Н. Калаев, Д. А. Иванов \\ Воронежский государственный университет \\ Поступила в редакцию 30 октября 2018 г.
}

\begin{abstract}
Аннотация: разработана модель оптимального использования минерально-сырьевой базы в условиях интенсивного воздействия антропогенных факторов на территории ЦЧР. Полученные результаты учитыввют состояние разведанных запасов и прогнозных ресурсов минерального сырья, возможности воспроизводства и развития минерально-сырьевой базы (МСБ), обеспеченность им предприятий региона и страны, дефицитные для них виды полезных ископаемых. Функиионирование по предложенной модели должно быть направлено на сохранение многообразных природных ресурсов и, по возможности, на достижение безотходной схемьи недропользования с постоянным воспроизводством МСБ. Представлены предложения по её основным направлениям воспроизводства, учитывающие необходимость существенной модернизации в соответствии со сложившейся сочиально-экономической ситуацией. Полученные результаты исследований при их внедрении позволят вести планирование развития производительных сил в ЦЧР, выбирать направления в поисках новых месторождений полезных ископаемых для воспроизводства МСБ. Разработка месторождений и использование экологического сырья в иелях охраны окружающей среды приведет к уменьшению содержаний вредных техногенных примесей в почвах и подземных водах. Полученные в ходе работ результаты могут быть использованы при региональном планировании развития производительных сил ЦЧР, совершенствованию территориальной политики в сфере природопользования, проведении поисково-разведочных и добычных работ в регионе.
\end{abstract}

Ключевые слова: окружающая среда, минерально-сырьевая база, минерально-экономическая оценка, экологическое состояние, модель, зоны экономического роста, недропользование.

\section{MINERAL-RAW MATERIAL BASE OF NON-METALLIC MINERAL RESOURCES OF CENTRAL BLACK EARTH REGION AND ITS RATIONAL USE. Article 2. THE MODEL OF RATIONAL USING OF MINERAL-RAW MATERIAL BASE OF NON-METALS}

\begin{abstract}
The model for the optimal use of the mineral-raw material base under the conditions of intensive influence of anthropogenic factors in the Central Black Earth region has been developed. The results take into account the state of explored reserves and inferred mineral materials resources, the possibility of reproduction and development of the mineral-raw material base, the sufficiency in raw materials for enterprises in the region and the country, the type of commercial minerals that are scarce for them. The functioning of the proposed model should be aimed at the preservation of varied natural resource and, if possible, the achievement of waste-free subsoil use scheme with constant reproduction of mineral-raw material base. Proposals for its main areas of reproduction are presented, taking into account the need for substantial modernization in accordance with the current socio-economic situation. The results of research in their implementation will allow planning the development of productive forces in the Central Black Earth region, choosing directions in the search for new mineral deposits for the reproduction of mineral-raw material base. The development of deposits and the use of ecological raw materials in aid of environment preservation will lead to a decrease in the content of harmful technogenic impurities in soils and groundwater. The results obtained in the course of work can be used in regional planning of development of the productive forces of the Central Black Earth region, improving the territorial policy in the field of natural resource use, exploration and mining in the region.
\end{abstract}


Key words: environment, mineral-raw material base, economic assessment of mineral resources, ecological state, model, economic growth areas, subsoil use.

Исходные данные, учтенные при построении модели

Основной целью создания модели оптимального использования минерально-сырьевой базы (МСБ) в условиях интенсивного воздействия антропогенных факторов является оценка её состояния, возможностей развития и прогноз изменения природной среды в результате горнодобывающих работ и передела добываемого сырья. Рациональное использование МСБ обязательно предполагает учет экологических последствий её освоения. Их индикаторами являются нарушение, изъятие, перемещение и переработка объёмов извлекаемых пород, а также связанные с этим различные виды загрязнения. Нарушения обусловлены механическим, гидродинамическим, взрывным и другими энергетическими видами воздействия, загрязнение - газопылевым, гидрохимическим, химическим видами воздействия. МСБ во многом определяет развитие различных отраслей промышленности и сельского хозяйства ЦЧР, а её использование ведет к экологическим рискам для окружающей среды, которые при построении модели должны быть учтены и сведены к минимуму.

Для территории ЦЧР, включающей Воронежскую, Курскую, Белгородскую, Липецкую и Орловскую области с общим населением 7,5 млн человек и богатыми природными ресурсами [1], характерна развитая многоотраслевая инфраструктура. Она включает многие населенные пункты, предприятия, сельскохозяйственные угодья, автомобильные и железные дороги, линии электропередач, газопроводы. В её пределах разрабатываются многие карьеры по добыче различных полезных ископаемых. Наиболее крупными по добыче и обогащению железных руд являются Михайловский в Курский, Стойленский и Лебединский ГОКи в Белгородской областях. Вскрышные и вмещающие породы этих месторождений являются сырьём для многих видов неметаллических полезных ископаемых [2].

Крупнейшими производителями металлургической продукции являются Новолипецкий и Оскольский железорудные комбинаты, электроэнергии атомные Нововоронежская и Курская электростанции. Многие территории в пределах и вокруг населенных пунктов являются промышленно-урбанизированными. Особенно это относится к градообразующим субъектам на базах добычи и передела минерального сырья.

Деятельность многих предприятий в той или иной мере ведет к истощению природных ресурсов, к которым относятся земельные, водные, лесные, минеральные, биологические [1]. Поэтому необходимы природоохранные мероприятия, связанные с затратами денежных средств, которые должны выделять субъекты предпринимательской деятельности и что должно быть учтено в предлагаемой модели.
Антропогенная деятельность оказала и обратное негативное влияние окружающей среды на производство различных видов продукции. Это обусловлено истощением ряда видов полезных ископаемых, уменьшением площадей лесных массивов и объёмов водных ресурсов, особенно подземных вод, что привело к ухудшению экологической ситуации. Увеличились территории техногенных образований, ускорились эрозионные процессы (рост оврагов, оползневых явлений, ухудшение состояния почв), появление техногенных ландшафтов при разработке карьеров.

Загрязненные атмосфера, почвы и водные бассейны угнетающе влияют на органический мир окружающей среды, что приводит к нарушениям циклов и дефектам в развитии фауны и флоры, угнетению и даже исчезновению некоторых видов и экосистем. Вместе с тем, рыночная экономика определяет ряд новых социально-экономических проблем. Главными из них являются необходимость занятости людей в трудовой деятельности, обеспечение им социальных гарантий, сохранение и развитие местной социальной инфраструктуры за счет сбора и использования налогов с предприятий по добыче и переделу минерального сырья. Всё это должно быть учтено при разработке модели оптимального развития МСБ региона, в которой помимо прогноза её наращивания и использования должны быть рассмотрены негативные последствия влияния на окружающую среду и их минимизация при добыче полезных ископаемых.

Оптимальная модель использования, воспроизводства и охраны минерального сырья должна включать: 1 - помимо него, учет и условия сохранения других ресурсов включающих водные, почвенные, лесные, биологические, их размещение и взаимодействие; 2 условия и факторы для минимизации негативного воздействия действующих предприятий на экологическое состояние окружающей среды; 3 - достижение наибольшего экономического эффекта и решение социальных задач при реализации модели.

Развитая МСБ ЦЧР, включающая свыше 600 месторождений различных видов минерального сырья, дает возможность не только использовать высокий промышленный потенциал своих предприятий, но и поставлять на экспорт ряд видов полезных ископаемых и полученную из них продукцию за пределы региона в другие области России и страны Европы и Азии. Помимо разрабатываемых месторождений железа, строительного, химического, технологического, керамического, формовочного сырья, пресных и минеральных подземных вод, разведаны месторождения медно-никелевых руд, дефицитных для страны титанциркониевых, стекольных, формовочных песков, бокситов, бентонитовых и каолиновых глин. Это создает возможности для дальнейшего развития горнодобывающей промышленности в регионе с весьма развитыми инфраструктурой и производительными силами. 
Спрос на минеральное сырье в Мире, в том числе и России, постоянно растет. В этом плане ЦЧР имеет неплохие перспективы по расширению МСБ за счет неметаллических полезных ископаемых. Это керамическое [3-6], кремнистое [7, 8], сорбционное [9], агрономическое [10], нетрадиционные для региона алмазы $[11,12]$ и некоторые другие виды минерального сырья.

В регионе действуют свыше 400 горнодобывающих предприятий, поставляющих сырьё для народного хозяйства. Это металлургическая, горно-химическая, пищевая, топливно-энергетическая, агропромышленная отрасли, строительная индустрия, дорожное строительство. На базе добычи и передела сырья месторождений построен ряд населенных пунктов, где проживает значительное количество населения. В результате появляются рабочие места, поступают налоги, улучшается социально-экономическое положение населения ЦЧР, особенно в Белгородской и Курской областях.

Предлагаемая модель развития МСБ предполагает широкое использование вскрышных и вмещающих пород на месторождениях основного добываемого сырья. Значительные объемы накопленных техногенных образований из отвалов вскрышных пород и хвостохранилищ ГОКов являются пополняемыми источниками минерального сырья, в первую очередь, строительного и технологического. Во вскрышных породах нередко содержатся ценные компоненты. Это фосфорит, ильменит, кварцевые пески, глауконит, почвенная органика. Хвосты обогащения несут магнетит, некоторые металлы, в том числе золото. Поэтому извлечение этих компонентов должно учитываться при разработке модели, поскольку безотходность производства удешевляет стоимость основной продукции и позитивно влияет на экологическое состояние окружающей среды, особенно при использовании природных сорбентов для очищения почв, подземных и поверхностных вод. Несомненные перспективы региона месторождения таких сорбентов доказаны геологами Воронежского университета.

При построении модели учитывается минеральноэкономическая составляющая, состояние инфраструктуры, экологическая ситуация, проблемы повышения уровня и качества жизни населения, его занятости, поступлений в региональный и местный бюджеты, сохранение природной и историко-культурной среды территории. ЦЧР является одним из наиболее комфортных для проживания населения регионов России с развитыми, хотя и неравномерно, инфраструктурой и МСБ. Помимо эксплуатируемых месторождений железа, строительного, химического сырья, без использования которого невозможно развитие региона, существуют значительные возможности введения в эксплуатацию нетрадиционных видов минерального сырья, что показано в работе [2].

Рассматриваемая модель (рис.1), [13]) является интегрированным продуктом, объединяющим огромный материал по природным ресурсам и состоянию окру- жающей среды. Прежде всего, предметом оценки является вся МСБ ЦЧР. Установлено, что её ресурсы используются недостаточно полно [2], хотя эта база дает возможность строительства новых предприятий и расширение работающих на потребности региона и для понижения импорта минерального сырья и изделий из него. Наличие запасов полезных ископаемых в регионе дают возможность не ввозить на его территорию многих из них, в том числе бентонитовые и тугоплавкие глины, стекольные и формовочные пески, месторождения которых разведаны в ЦЧР.

Уровень техногенной нагрузки оценивался по следующим оценочным критериям, которые отражают воздействие (показатели) на ландшафты [14].

1 - эмиссионная нагрузка по учету объёмов поступающих загрязняющих веществ в воздух от стационарных и передвижных источников загрязнения (т / год на $\left.1 \mathrm{\kappa м}^{2}\right)$;

2 - нагрузка загрязняющими веществами поверхностных вод поступающими в водоемы сточными (млн м ${ }^{3}$ сбросов / млн м ${ }^{3}$ местного естественного речного стока);

3 - нагрузка на почвы - учет химизации сельскохозяйственных угодий (объём минеральных удобрений 1 га пашни: кг/га).

Обязательный компонент модели - инфраструктурные особенности региона:

1 - реки, озера, пруды и водохранилища; каждый объект имеет охранную зону и может использоваться для водоснабжения или транспортировки грузов;

2 - автомобильные дороги, служащие основной для транспортировки грузов, и где от автотранспорта происходит загрязнение атмосферы;

3 - железные дороги, через которые проходит основной поток грузов;

4 - лесные массивы, заповедники, заказники, национальные парки, выделяются как участки, исключенные из сферы деятельности горнодобывающей промышленности и тяжелых геологоразведочных работ;

5 - газопроводы и нефтепроводы;

6 - горная промышленность (горнорудные предприятия, горные комбинаты, заводы строительных материалов, обогатительные предприятия);

7 - районные центры, учитываемые как транспортные узлы и показывающие демографическую ситуацию в районе.

Минерально-экономическое районирование (МЭР) - метод анализа, позволяющий определять и сравнивать существующие потенциальные возможности развития производительных сил в различных районах. По принципу районирования выбираются объекты, представляющие наибольший интерес для региона с наименьшими затратами и максимальной экономической отдачей. МЭР заключается в проведении укрупненной геолого-экономической оценки месторождений полезных ископаемых региона, разделение его на районы с набольшей и наименьшей потенциальной ценностью недр с последующим построением карт на основе выполненного анализа. 
Расчет товарной стоимости запасов учитывает запасы минерального сырья и наличие полезных компонентов ему сопутствующих. Он включает промышленные запасы категории $\mathrm{A}+\mathrm{B}+\mathrm{C}_{1}$ и запасы категории $\mathrm{C}_{2}$. Основное содержание минерально-экономической карты определяется пространственно-временным мониторингом минерально-сырьевой базы региона с использованием районирования, выполняемого для поддержки управленческих решений и привлечения инвестиций для освоения МСБ [15].

МЭР позволяет решать вопросы распределения производительных сил и значение минеральносырьевого потенциала в экономике региона. Это требует большого объёма комплексных знаний о ЦЧР, отражающих взаимосвязь и пространственное распределение геологических, стоимостных, минерально-сырьевых и инфраструктурных позиций. Основой для построения служит прогнозная карта, на которую вынесены неглубоко залегающие породы: а) титанциркониевые россыпи; б) доломиты; в) известняки; г) песчано-гравийные смеси; д) формовочные; е) стекольные; ж) глауконитсодержащие пески; 3) тугоплавкие и огнеупорные глины; и) бентонитовые, к) кремнистые глины.

В ходе проведения геолого-экономического дифференцирования ЦЧР проведено ранжирование территории и выделены три зоны освоения: а) стабильного; б) дальнесрочного; в) с неопределенными перспективами [16].

\section{Зоны стабильного освоения}

Включают территории с развитой инфраструктурой, для которых характерно устойчивое экономическое развитие со стабильной добычей и переработкой минерального сырья. Проведение геологоразведочных работ необходимо для прироста запасов и доразведки уже известных и разрабатываемых месторождений. Это следующие зоны:

1 - Старооскольская в Губкинском и Старооскольском районах Белгородской области, где эксплуатируются крупные Коробковское, Лебединское, Стойленское и Стойло-Лебединское железорудные месторождения. Из вскрышных и вмещающих пород получают строительные камни, мел, кирпичночерепичное сырье, пески формовочные и строительные, карбонатные породы для минеральной подкормки. Возможен значительный прирост полезных ископаемых, в том числе неметаллов.

2 - Железногорская в Курской области. Здесь Михайловское месторождение, обеспечивает 29 \% общероссийской добычи железных руд и 13,3 \% запасов России [17]. Прирост запасов железорудного сырья значительный, за счет ввода в разработку Курбакинского месторождения, числящегося на госбалансе. Во вскрышных и вмещающих породах имеется ряд видов неметаллических полезных ископаемых.

3 - Данковская в одноименном районе Липецкой области. Здесь находится крупное разрабатываемое месторождение доломитов. При его доразведке воз- можен значительный прирост запасов. В пределах зоны имеются цирконий-титановые россыпи, из вмещающих пород которых при гидроклассификации помимо тяжелых минералов возможно получение кварцевых стекольных песков.

4 - Липецкая, в Липецком районе. В ней эксплуатируются крупные месторождения флюсовых и цементных известняков (Сокольско-Ситовское), тугоплавких глин, строительных песков и кирпичночерепичного сырья.

5 - Елеикая в Липецкой области. Здесь имеются значительные запасы карбонатного сырья, функционируют крупные Аргамачское, Ольшанецкое, Лавское, Воргольское карбонатные месторождения, поставляющие флюсовое, химическое, стекольное сырьё, строительные камни и Чибисовское месторождение тугоплавких глин. Кроме того, добываются строительные пески и кирпично-черепичного сырьё.

6 - Павловская (юг Воронежской области), где на крупном Шкурлатовском месторождении гранитов добываются строительные камни. Во вскрыше подсчитаны запасы вулканогенно-осадочного ильменита, мелов и кирпичных суглинков. Недалеко разведано подобное Казинское месторождение.

7 - Северо-Западно-Воронежская, Семилукский и Хохольский районы. В этой зоне разрабатываются месторождения Латненской группы. Ведется добыча огнеупорных и тугоплавких глин, строительных и силикатных песков, кирпично-черепичного и керамзитового сырья, разведано Богдановское месторождение стекольных песков. Запасы огнеупорных глин ограничены, но тугоплавкого сырья значительны.

\section{Зоны дальнесрочного освоения}

Включают территории, где разведаны месторождения и имеются существенные объемы прогнозных ресурсов различных полезных ископаемых, которые не разрабатываются. Большая часть таких зон тяготеет к восточной части ЦЧР, включающей Липецкую, Тамбовскую и Воронежскую области. В них горнодобывающая промышленность развита намного слабее, чем на КМА. Но здесь имеются серьёзные предпосылки для добычи полезных ископаемых и развития связанных с ней сопутствующих производств, что обосновано: а) возможностями освоения медноникелевых месторождений в Воронежской, титанциркониевых россыпных и карбонатных в Тамбовской и Липецкой областях; б) обилием здесь месторождений и проявлений неметаллов, в) избытком рабочей силы в сельских районах; г) благополучной экологической ситуацией из-за отсутствия крупных предприятий.

Всё это предполагает возможности образования в этой части ЦЧР центров ускоренного экономического роста на базе имеющегося минерального сырья и связанных с ним предприятий по его переделу. К таким центрам следует отнести зоны:

1 - Южно-Воронежскую, Верхнемамонский район. В этой зоне имеются гранитное Казинское, гра- 
фитовое Сухоярское, медно-никелевые Подколодновское и Нижнемамонское месторождения, которые вместе с расположенным севернее Еланским представляют новую никеленосную провинцию России. В осадочном чехле развиты, титаноносные вулкано-

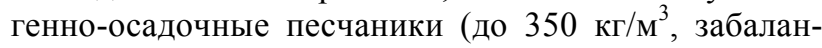
совые запасы условного ильменита 12,838 млн т, в пересчете: $\mathrm{TiO}_{2}-5,1, \mathrm{ZrO}_{2}-0,116$ млн т), базальты (сырьё для балластного щебня и каменного литья, прогнозные ресурсы по $\mathrm{P}_{2} 425,0$ млн м ${ }^{3}$ ), вторичные каолины, стекольные и формовочные пески, мела, кирпичные суглинки. Данные стоимостной оценки минерального сырья только в Верхнемамонском районе показаны в табл. 1.

2 - Рассказовскую, в одноименном районе Тамбовской области, где находится крупнейшее в Мире титан-циркониевое россыпное месторождение Центральное, расположенное в 60 км к востоку от Тамбова. Подобные, но меньшие по запасам россыпи, имеются в соседнем Кирсановском районе. Кроме минералов титана и циркония россыпи содержат глауконит, желваки фосфоритов, кварц. Выделение вместе с тяжелыми минералами только глауконита методами гидроклассификации и электромагнитной сепарации значительно повысит рентабельность разработки месторождения.

3 - Северо-Липецкую (Добровский и ЛевТолстовский районы). Она включает доломитовые проявления и месторождения, титан-циркониевые россыпи и стекольные пески. В Липецкой области имеются многие крупные предприятия металлургической, машиностроительной, горнодобывающей и перерабатывающей промышленности, строительной индустрии и агропромышленного комплекса. Их развитие во многом определяет состояние собственной минерально-сырьевой базы. Её состояние позволяет не только поддерживать промышленный потенциал, но наращивать его.

Из неглубоко залегающих аптских отложений, с проявлениями титан-циркониевых россыпей, в существенно кварцевых песках при гидроклассификации возможно получение стекольных и формовочных песков. Прогнозные ресурсы в рассматриваемой зоне по $\mathrm{P}_{2}$ для $\mathrm{TiO}_{2}$ составляют 5880, $\mathrm{ZrO}_{2}-1210$, стекольных песков - 1355770 тыс. т. В Лев-Толстовском районе, сосредоточены участки доломитового сырья с прогнозными ресурсами около 16 млн т по категории $\mathrm{P}_{2}$ (см. табл. 1).

4 - Щигровскую в Курской области. В ней имеется серия месторождений фосфоритов, сосредоточенных в Советском, Черемисиновском, Щигровском и Золотухинском районах. В первых двух находятся Кошелевское, Мармыжанское, Седеловское, Красная поляна, Покровское, Трухачевское месторождения, отработка которых целесообразна в первую очередь. Перспективы наращивания запасов фосфатного сырья представляются значительными.

Таблица 1

Расчетные данные по стоимости недр,

не учтенные государственным балансом запасов, в пределах зон дальнесрочного освоения

\begin{tabular}{|c|c|c|c|c|c|c|}
\hline $\begin{array}{c}\text { Зона } \\
\text { освоения }\end{array}$ & Район & $\begin{array}{c}\text { Вид } \\
\text { минерального сырья }\end{array}$ & $\begin{array}{c}\text { Категория } \\
\text { запасов } \\
\text { (ресурсов) }\end{array}$ & $\begin{array}{c}\text { Единица } \\
\text { измерения }\end{array}$ & $\begin{array}{c}\text { Количество } \\
\text { запасов } \\
\text { (ресурсов) }\end{array}$ & $\begin{array}{c}\text { Стоимость } \\
\text { сырья, } \\
\text { (тыс. \$*) }\end{array}$ \\
\hline \multirow{8}{*}{$\begin{array}{l}\text { Южно- } \\
\text { Воронеж- } \\
\text { ская }\end{array}$} & \multirow{7}{*}{ Верхнемамонский } & Титан & $\mathrm{C}_{2}$ & тыс. т & 5100,0 & 2956922,9 \\
\hline & & Цирконий & $\mathrm{C}_{2}$ & тыс. т & 116,0 & 31733,42 \\
\hline & & Графит & $\mathrm{P}_{1}$ & тыс. т & 17300 & 2108178,0 \\
\hline & & Базальт & $\mathrm{P}_{2}$ & тыс. $\mathrm{M}^{3}$ & 425000,0 & 30714,75 \\
\hline & & Никель & $\mathrm{C}_{2}$ & тыс. т & 147,77 & 410451,40 \\
\hline & & Медь & $\mathrm{C}_{2}$ & тыс. т & 91,0 & 96752,63 \\
\hline & & Кобальт & $\mathrm{C}_{2}$ & тыс. т & 11,45 & 41214,61 \\
\hline & \multicolumn{6}{|c|}{$\begin{array}{l}\text { Стоимость недр Верхнемамонского района составляет - } 5675967,70 \text { тыс. \$* } \\
\text { Удельная стоимость недр этого района составляет }-4204,42 \text { тыс.\$* }\end{array}$} \\
\hline \multirow{8}{*}{$\begin{array}{l}\text { Северо- } \\
\text { Липецкая }\end{array}$} & \multirow{3}{*}{ Добровский } & Титан & $\mathrm{P}_{2}$ & тыс. т & 2940,0 & 716513,28 \\
\hline & & Цирконий & $\mathrm{P}_{2}$ & тыс. т & 1600,0 & 73434,9 \\
\hline & & Стекольные пески & $\mathrm{P}_{1}$ & тыс. т & 45800 & 699651,79 \\
\hline & \multicolumn{6}{|c|}{$\begin{array}{l}\text { Стоимость недр Добровского района } 1489599,97 \text { тыс. } \$ * \\
\text { Удельная стоимость недр Верхнемамонского района } 1132,776 \text { тыс. } \$ *\end{array}$} \\
\hline & \multirow{4}{*}{ Лев-Толстовский } & Доломит & $\mathrm{P}_{2}$ & тыс. т & 71900,0 & 1860,41 \\
\hline & & Титан & $\mathrm{P} 2$ & тыс. т & 2940,0 & 716513,28 \\
\hline & & Цирконий & $\mathrm{P}_{2}$ & тыс. т & 600,0 & 73434,9 \\
\hline & & Стекольные пески & $\mathrm{P}_{3}$ & тыс. т & 93970,0 & 13261,05 \\
\hline & \multicolumn{6}{|c|}{$\begin{array}{l}\text { Стоимость недр Лев-Толстовского района составляет - } 805069,64 \text { тыс. } \$ * \\
\text { Удельная стоимость недр Верхнемамонского района составляет - 829,97 тыс. \$* }\end{array}$} \\
\hline
\end{tabular}

Примечание: * - без учета стоимости минерального сырья числящегося на балансе. 
Зоны с неопределенными перспективами освоения В них имеются месторождения полезных, в том числе и крупных, но их освоение в ближайшем будущем экономически нецелесообразно в силу разных причин. Вместе с тем геологоразведочные работы необходимо продолжить для поисков новых видов полезных ископаемых, а также для наращивания запасов на перспективных месторождениях. К таким зонам относятся:

1. - Дмитровская, в Орловской области, где разведано крупное Новоялтинское железорудное месторождение. Нецелесообразность его разработки, в том числе использования вскрышных пород с нерудными полезными ископаемыми, обусловлено нахождением рядом разрабатываемого Михайловского железорудного месторождения.

2. - Чернянская в Белгородской области, где разведаны крупные Приоскольское, Чернянское и Погромецкое железорудные месторождения. В настоящее время потребности России в качественных железных рудах удовлетворяются их поставкой из таких же месторождений в соседних Губкинском и Старооскольском районах.

3. - Белгородско-Щебекинская, где имеются бокситовые и железорудные месторождения. Они перекрыты мощным чехлом осадочных образований с водоносными горизонтами. Поэтому в ближайшем будущем их рентабельная разработка под большим вопросом. Опробованный на Яковлевском железорудном месторождении шахтный способ отработки потребовал больших финансовых затрат при невысокой рентабельности. Перспективным представляется гидроскважинный метод для рыхлых руд, примененный на Большетроицком месторождении, требуемый совершенствования технологии.

4. - Юго-Восточно-Воронежская, на территории Воробьевского, Калачеевского и Петропавловского районов. Основным полезным ископаемым этой зоны являются верхнедевонские вторичные каолины и переслаивающиеся с ними кварцевые пески различного назначения. Это стекольные, формовочные и строительные разности. Здесь разведано такое месторождение Козынка - первое в пределах Европейской части России. Перспективы обнаружения новых месторождений подобного типа весьма высокие. Добыча песчано-каолинового сырья может вестись как открытым, так и гидроскважинным способами. Последний способ экологичен и высокорентабелен. Имеются большие перспективы открытия залежей бентонитовых глин, аналогичных разрабатываемым на Никольском месторождении.

5. - Еланьская, Воронежская область. Базируется на освоении недавно разведанного крупного медноникелевого Еланьского месторождения. Добыча предполагается шахтным способом. Планируется строительство ГОКа, из которого рудный концентрат будет транспортироваться на Урал для металлургического передела.

При построении модели оптимального использования МСБ был необходим учет влияния антропогенных факторов на окружающую среду. Для определения степени антропогенной нагрузки при разработке месторождений были выбраны опорные районы с различными медико-экологическими показателями и объемами добычи сырья в кубометрах (табл. 2). Для оценки нагрузки на окружающую среду при введении в эксплуатацию месторождений зон дальнесрочного освоения предполагаемые объемы добычи выбирались путем аналогий с действующими горными предприятиями. Использовались данные, представленные в государственных балансах запасов, государственных докладах о состоянии и использовании минерально-сырьевых ресурсов Российской Федерации и других источников [17-19]. Предполагаемые виды добычи представлены в табл. 3 .

Таблица 2

Объемы и виды добываемого сырья по опорным районам

\begin{tabular}{|c|c|c|c|}
\hline $\begin{array}{c}\text { Район (медико- } \\
\text { экологическая нагрузка) }\end{array}$ & Месторождение & Вид минерального сырья & $\begin{array}{l}\text { Годовой объем } \\
\text { добычи в тыс. м }\end{array}$ \\
\hline 1 & 2 & 3 & 4 \\
\hline \multirow[t]{2}{*}{$\begin{array}{l}\text { Губкинский } \\
\text { (высокий) }\end{array}$} & $\begin{array}{l}\text { Коробковское } \\
\text { Лебединское } \\
\text { Лебединское } \\
\text { Лебединское } \\
\text { Лебединское } \\
\text { Лебединское } \\
\text { Стойло-Лебединское } \\
\text { Стойло-Лебединское }\end{array}$ & $\begin{array}{l}\text { железные руды } \\
\text { пески строительные } \\
\text { кирпично-черепичное } \\
\text { строительные камни } \\
\text { мел } \\
\text { железные руды } \\
\text { строительные камни } \\
\text { железные руды }\end{array}$ & $\begin{array}{c}771,196 \\
2365,0 \\
320,0 \\
395,0 \\
411,111 \\
4740,652 \\
216,0 \\
5176,739\end{array}$ \\
\hline & & & 14395,698 \\
\hline \multirow[t]{2}{*}{$\begin{array}{l}\text { Задонский } \\
\text { (высокий) }\end{array}$} & $\begin{array}{l}\text { Хмелинецкое } \\
\text { Лукошкинское } \\
\text { Улусарское } \\
\text { Синявское }\end{array}$ & $\begin{array}{c}\text { карбонатное технологическое } \\
\text { глины тугоплавкие } \\
\text { пески строительные } \\
\text { пески силикатные }\end{array}$ & $\begin{array}{c}151,396 \\
152,278 \\
203,2 \\
220,4\end{array}$ \\
\hline & & & 727,274 \\
\hline $\begin{array}{l}\text { Елецкий } \\
\text { (повышенный) }\end{array}$ & $\begin{array}{l}\text { Елецкое } \\
\text { Елецкое } \\
\text { Ольховецкий участок } \\
\end{array}$ & $\begin{array}{l}\text { кирпично-черепичное сырье } \\
\text { карбонатное строительное } \\
\text { пески строительные }\end{array}$ & $\begin{array}{c}5,0 \\
198,2 \\
85,20\end{array}$ \\
\hline
\end{tabular}


Продолжение табл. 2

\begin{tabular}{|c|c|c|c|}
\hline 1 & 2 & 3 & 4 \\
\hline \multirow[t]{2}{*}{$\begin{array}{l}\text { Елецкий } \\
\text { (повышенный) }\end{array}$} & $\begin{array}{l}\text { Ольшанский участок } \\
\text { Чибисовское } \\
\text { Чибисовское } \\
\text { Аргамачское } \\
\text { Воргольское } \\
\text { Голиковское } \\
\text { Лавское } \\
\text { Ольшанецкое }\end{array}$ & $\begin{array}{l}\text { пески строительные } \\
\text { кирпично-черепичное сырье } \\
\text { глины тугоплавкие } \\
\text { строительные камни } \\
\text { карбонатное строительное } \\
\text { строительные камни (граниты, } \\
\text { известняки, песчаники) } \\
\text { строительные камни } \\
\text { карбонатное металлургическое }\end{array}$ & $\begin{array}{c}1438,0 \\
8,3 \\
24,778 \\
557,0 \\
8,1 \\
262 \\
237,0 \\
553,077\end{array}$ \\
\hline & & & 3376,655 \\
\hline \multirow[t]{2}{*}{$\begin{array}{l}\text { Семилукский } \\
\text { (повышенный) }\end{array}$} & $\begin{array}{l}\text { Дорожное } \\
\text { Латненское } \\
\text { Латненское } \\
\text { Латненское } \\
\text { Латненское }\end{array}$ & $\begin{array}{l}\text { кирпично-черепичное } \\
\text { кирпично-черепичное } \\
\text { глины огнеупорные } \\
\text { керамзитовое сырье } \\
\text { пески силикатные }\end{array}$ & $\begin{array}{c}44,0 \\
28,0 \\
185,556 \\
107,0 \\
42,0\end{array}$ \\
\hline & & & 406,556 \\
\hline \multirow[t]{2}{*}{ Павловский (средний) } & Шкурлатское & строительные камни (гранит) & 4315,0 \\
\hline & & & 4315,0 \\
\hline \multirow[t]{2}{*}{ Советский (средний) } & Большая Карповка & $\begin{array}{l}\text { глины тугоплавкие } \\
\text { пески строительные }\end{array}$ & $\begin{array}{c}186,667 \\
34,0 \\
\end{array}$ \\
\hline & & & 220,667 \\
\hline \multirow[t]{2}{*}{ Моршанский } & $\begin{array}{l}\text { Моршанское } 1 \\
\text { Пичаевский участок }\end{array}$ & $\begin{array}{l}\text { кирпично-черепичное } \\
\text { пески силикатные }\end{array}$ & $\begin{array}{c}2,05 \\
10\end{array}$ \\
\hline & & & 12,05 \\
\hline \multirow[t]{2}{*}{ Краснозоренский } & Краснозоренское & пески строительные & 24,0 \\
\hline & & & 24,0 \\
\hline \multirow[t]{2}{*}{ Тимский } & Канищевский участок & пески силикатные & 9,0 \\
\hline & & & 9,0 \\
\hline \multirow[t]{2}{*}{ Волоконовский } & $\begin{array}{l}\text { Козловский участок } \\
\text { Волоконовское II }\end{array}$ & $\begin{array}{l}\text { пески силикатные } \\
\text { кирпично-черепичное }\end{array}$ & $\begin{array}{c}61,0 \\
4,0\end{array}$ \\
\hline & & & 65,0 \\
\hline
\end{tabular}

Таблица 3

Предполагаемые объемы добычи минерального сырья в зонах освоения

\begin{tabular}{|c|c|c|c|c|}
\hline Зона освоения & Район & $\begin{array}{c}\text { Вид минерального } \\
\text { сырья }\end{array}$ & $\begin{array}{c}\text { Предполагаемый } \\
\text { годовой объем } \\
\text { добычи, тыс. т }\end{array}$ & $\begin{array}{c}\text { Предполагаемый } \\
\text { объем добычи, } \\
\text { тыс. } \text { м }^{3}\end{array}$ \\
\hline Еланская & Новохоперский & $\mathrm{Cu}-\mathrm{Ni}$ руды & 4500 & 1500 \\
\hline Рассказовская & Рассказовский & Zr-Ti руды & 4000 & 2000 \\
\hline \multirow{5}{*}{$\begin{array}{l}\text { Северо- } \\
\text { Липецкая }\end{array}$} & \multirow{3}{*}{ Лев-Толстовский } & доломит & 5000 & 2000 \\
\hline & & Zr-Ti руды & 4000 & 2000 \\
\hline & & стекольные пески & 4000 & 2000 \\
\hline & \multirow{2}{*}{ Добровский } & Zr-Ti руды & 4000 & 2000 \\
\hline & & стекольные пески & 4000 & 2000 \\
\hline \multirow{3}{*}{ Щигровская } & Черемисиновский & фосфатное сырье & 100 & 50 \\
\hline & \multirow{2}{*}{ Советский } & фосфатное сырье & 100 & 50 \\
\hline & & Ti-Zr руды & 3000 & 1500 \\
\hline \multirow{3}{*}{$\begin{array}{c}\text { Южно- } \\
\text { Воронежская }\end{array}$} & \multirow{3}{*}{ Верхнемамонский } & графитовые руды & 40 & 14 \\
\hline & & $\begin{array}{c}\text { строительный камень } \\
\text { (базальт) }\end{array}$ & 3000 & 3000 \\
\hline & & $\mathrm{Cu}-\mathrm{Ni}$ руды & 4500 & 1500 \\
\hline
\end{tabular}

\section{Описание разработанной модели}

Построение модели проводилось с использованием регионального подхода, учитывающего развитие производительных сил, экономико-географическое положение, состояние инфраструктуры, экологическую ситуацию, проблемы повышения уровня и каче- ства жизни населения, его занятости, поступления в региональный и местный бюджеты, сохранение природной и историко-культурной среды территории. В этом плане, ЦЧР является одним из наиболее комфортных для проживания населения регионов России, с развитой, хотя и неравномерно, инфраструктурой. 
Учитывались разведанные запасы и прогнозные ресурсы полезных ископаемых, воспроизводство и развитие МСБ, обеспеченность им предприятий региона и страны, дефицитные для них виды минерального сырья. Основные финансовые поступления от продажи минерального сырья для региона связаны с разработкой железных руд Старооскольского и Михайловского месторождений. Для развития инфраструктуры важнейшее значение имеют неметаллические виды полезных ископаемых, в первую очередь, строительного (цементного, песчаного, глинистого, карбонатного), химического, технологического и агрономического сырья.

В пределах выделенных зон экономического роста, должны учитываться их воздействие при отработке месторождений на природную среду. В связи с этим целесообразно ввести градацию месторождений. В зависимости от типа полезного ископаемого выделяются две группы месторождений: А - при добыче и переделе минерального сырья которого происходит загрязнение газопылевым, гидрохимическим, химическим видами окружающей среды (железные и медноникелевые руды, фосфориты); группа Б - загрязнение преимущественно газопылевым видом воздействия на природную среду (строительное, технологическое, каолины, бентониты и др.). Экологические последствия от нарушения механическим, гидродинамическим, взрывным и другими энергетическими видами воздействия, а также от изъятия природных ресурсов для обеих групп принимается сходным.

Эксплуатация стратегически важного типа сырья (цирконий-титановых россыпей) предпочтительней разработки медно-никелевых месторождений, поскольку титан и цирконий страна импортирует, а медь и никель экспортирует в больших объёмах. Медноникелевые месторождения, залегающие на глубинах от 300 и более метров, могут эксплуатироваться только шахтным способом. При этом необходимо создание обогатительной фабрики для получения сульфидного концентрата никеля, меди и кобальта, что повлечет за собой загрязнение окружающей среды (почв, атмосферы, поверхностных и подземных вод), неблагоприятное воздействие на флору и фауну. Концентрат придется доставлять на плавильный завод на Урале, что также негативно скажется на окружающей среде. С другой стороны, добыча цирконийтитановых руд Центрального месторождения в Тамбовской области, одного из самых крупных в Мире. Россыпи находятся в приповерхностном залегании (от 1 до 40 м), могут разрабатываться неглубокими карьерами. Получение концентрата возможно экологически чистым способом гидроклассификации. Вмещающие россыпи глауконит-кварцевые пески представляют собой источник получения глауконита, являющегося агросырьем и материалом для получения качественных красок, что на 40 \% повышает рентабельность разработки месторождения. Хвосты обогащения, содержащие фосфаты, являются прекрасным материалом для целей рекультивации. Как показал опыт разработки песков с фосфоритами Полпинского месторождения в Брянской области, на рекультивированных землях возможно создание высокопродуктивных сосновых массивов.

При добыче фосфоритов загрязнения среды не происходит, но при переделе этого сырья для получения фосфмуки используются различные реагенты, приводящие к ухудшению экологической ситуации. Поэтому месторождения фосфоритов отнесены к группе А. Это ценное агрономическое сырьё обычно ассоциирует с глауконитовым, являющимся источником калия.

Наибольшее значение в качестве строительных материалов имеют известняки и доломиты Липецкой и Орловской областей, граниты и базальты юговосточной части Воронежской области. Из гранита получают высококачественный щебень, пользующийся повышенным спросом. Из базальтов возможно производство крайне дефицитного балластного щебня. Последний применяется для прокладки железных дорог. Месторождения карбонатных пород осваиваются уже давно чрезвычайно развитыми строительной и металлургической (флюсы) отраслями. Базальты в качестве балластного щебня и каменного литья для нашей территории предлагаются впервые.

Базой модели (см. рис. 1), служит карта месторождений полезных ископаемых ЦЧР [13]. На неё нанесена следующая информация: 1. - Минеральноэкономическая карта; 2. - Геолого-экономическая карта с выделенными зонами экономического роста на базе разработки и передела различных видов минерального сырья с очередностью их освоения; 3. Рекреационные зоны (реки, озера, водохранилища, лесные массивы, заповедники), где исключается ведение горнодобывающих работ и размещение предприятий; 4. - Инфраструктурные особенности региона (численность населения, авто- и железные дороги, путепроводы и т.д.).

Карта расположения полезных ископаемых составлена в соответствии с требованиями, предъявляемыми при построении карт масштаба 1:1 000000 [20]. Карта расположения полезных ископаемых составлялась в форме ГИС, с использованием программного продукта ArcView. Объектами картографирования являлись месторождения, учтенные государственным балансом запасов. Каждое месторождению, в зависимости от объема запасов, было ранжировано. Размер знаков их форма и цвет зависит от ранга месторождения и вида сырья. В зависимости от статуса месторождения (распределенной или нераспределенный фонд), их названия имеют различный цвет.

Базовая карта сопровождается дополнительными материалами: Схемами: а) эмиссионной нагрузкой на атмосферу с цитогенетическими показателями, б) удельной техногенной нагрузки на водные ресурсы, в) антропогенной нагрузки на земельные ресурсы, г) плотности линейной эрозии, д) ввоза - вывоза минерального сырья, е) инфраструктуры минеральносырьевого комплекса, ж) рейтинга напряженности 
медико-экологической ситуации; з) таблицей антропогенной нагрузки в зонах дальнесрочного освоения.

На карте месторождений полезные ископаемые показаны по видам. Это глины огнеупорные, тугоплавкие, бентонитовые, сырье стекольное, цементное, карбонатное технологическое и металлургическое, фосфатное, кремнистое, кирпично-черепичное, керамзитовое, карбонатное строительное для минеральной подкормки, бокситы, железные, никелевые, медные руды, титан, цирконий, пески формовочные, строительные, силикатные, песчано-гравийные смеси, строительные камни (граниты, известняки, песчаники), мел, минеральные краски.

При построении минерально-экономической карты учитывалось минерально-экономическое районирование - метод территориального анализа, позволяющий определять и сравнивать существующие потенциальные возможности развития производительных сил в различных районах. Пользуясь принципом районирования объективно выбирались объекты с наименьшими затратами и максимальной отдачей при освоении, представляющие наибольший интерес для региона.

Результаты, полученные при минеральноэкономической оценке ЦЧР, сведены на картографическую основу масштаба 1:1000 000 (см. рис. 1). На карте в пределах областей выделены районы и с учетом расчетных показателей показана их потенциальная удельная стоимость. Минерально-экономическое районирование производилось по принципу административного деления на районы, в пределах областей входящих в состав ЦЧР. В зависимости от удельной стоимости недр принято деление на пять классов. При подсчете учитывался как распределенный, так и нераспределенный фонд недр района.

Одним из важнейших инструментов, с помощью которых возможно решать задачи распределения производительных сил и значение минерально-сырьевых ресурсов в социально-экономическом развитии региона, служит геолого-экономическая карта. Она включает обширную геологическую информацию о регионе и является интегрирующим продуктом. Она отражает взаимосвязь пространственного распределения геологической, стоимостной, минерально-сырьевой и инфраструктурной информации. В результате геолого-экономического дифференцирования ЦЧР выделены зоны экономического роста, основанные на разведанных и прогнозных ресурсах полезных ископаемых. Карта МЭР показывает неравномерность размещения месторождений полезных ископаемых. На основании анализа МСБ в регионе определены зоны экономического освоения. В зависимости от ранжирования они имеют индивидуальное отображение со штриховкой. Зоны стабильного освоения показаны красным цветом, дальнесрочного - синим, а с неопределенными перспективами освоения - черным.

При построении модели использования минерально-сырьевой базы в условиях интенсивного воздействия антропогенных факторов учитывался ряд показателей состояния окружающей среды (OC) техноген- ного характера, связанных с воздействием различных отраслей промышленности и общества на ОС и биоиндикационные показатели, отражающие реакцию флоры и человека на это воздействие. Эти показатели имеют кумулятивный или накопительный характер за счет многофакторных условий их формирования. Одним из таких факторов, вносящих свой вклад в техногенные и естественные природные процессы, является горнодобывающая и перерабатывающая промышленность, функционирующая в рамках существующих природно-техногенных агломераций. При обработке значений показателей они были усреднены для административных районов и крупных населенных пунктов (152 территориальных образования) [13].

Для характеристики эмиссионной нагрузки на атмосферу, плотности линейной эрозии, антропогенной нагрузки на земельные ресурсы (распаханность), удельной техногенной нагрузки на водные ресурсы использована форма графического представления показателей - равноинтервальная цветовая шкала. Шаг интервалов выбран в соответствии с индивидуальными диапазонами данных по каждому из признаков с учетом целочисленных или кратных им граничных значений при общем числе классов, не превышающем шести, что является оптимальным для цветового картографического представления. Для данных по плотности линейной эрозии и удельной техногенной нагрузки на водные ресурсы, кроме этого, применена детализация классов в области низких значений, ввиду их широкого пространственного распространения. В общем случае, данные классификации применимы для бально-рейтингового ранжирования показателей по уровням потери качества ОС относительно экологических норм, как способ альтернативный нормированию данных при комплексной оценке состояния окружающей среды. Значения классов по данным показателя приведены в табл. 4.

Для показателей состояния среды по значению цитогенетических данных, плотности линейной эрозии, усредненной на район, объемов вносимых минеральных удобрений в пахотные земли, объемов сбрасываемых загрязненных сточных вод в поверхностные водоемы использованы формы картографического представления. Для наглядности карты наложены на соответствующие тематические площадные картысхемы зарамочного оформления модели (см. рис. 1). Значения классов по данным показателей приведены в табл. 5. Кроме этого, для оценки корреляционных связей с техногенными показателями были привлечены показатели здоровья населения (взрослого, детского и заболеваемость новообразованиями), также привязанные к территориальным образованиям.

На рис.2 приведена схема эмиссионной нагрузки на атмосферу ЦЧР. Максимальные значения объема выбросов загрязняющих веществ отмечаются для территории городского округа Воронеж как индустриальной промышленно-транспортной зоны, Губкинского, Старооскольского районов Белгородской области, где интенсивно развита горнодобывающая и 
Таблица 4

Классы техногенных показателей первой группь

\begin{tabular}{|c|c|c|c|c|}
\hline \multirow{2}{*}{$\begin{array}{c}\text { Номер } \\
\text { класса }\end{array}$} & \multicolumn{4}{|c|}{ Значение показателя } \\
\cline { 2 - 5 } & $\begin{array}{c}\text { Эмиссионная } \\
\text { нагрузка, } \\
\text { (т в год/км }{ }^{2}\end{array}$ & $\begin{array}{c}\text { Плотность } \\
\text { линейной эрозии, } \\
\left(\text { км/км }{ }^{2}\right.\end{array}$ & $\begin{array}{c}\text { Распахан- } \\
\text { ность, }(\%)\end{array}$ & $\begin{array}{c}\text { Удельная } \\
\text { техногенная нагрузка } \\
\text { на водные ресурсы }\end{array}$ \\
\hline 1 & $<2,5$ & $<0,05$ & $<50$ & $<2$ \\
\hline 2 & $2,5-5$ & $0,05-0,1$ & $50-55$ & $2-5$ \\
\hline 3 & $5-7,5$ & $0,1-0,2$ & $55-60$ & $5-15$ \\
\hline 4 & $7,5-10$ & $0,2-0,4$ & $60-65$ & $15-25$ \\
\hline 5 & $10-12,5$ & $0,4-0,6$ & $65-70$ & $>25$ \\
\hline 6 & $>12,5$ & $>0,6$ & $>70$ & - \\
\hline
\end{tabular}

Таблица 5

Классы техногенных показателей второй группь

\begin{tabular}{|c|c|c|c|c|}
\hline \multirow{2}{*}{$\begin{array}{c}\text { Номер } \\
\text { класса }\end{array}$} & $\begin{array}{c}\text { Состояние среды по цито- } \\
\text { генетическим данным }\end{array}$ & $\begin{array}{c}\text { Плотность линей- } \\
\left.\text { ной эрозии, (м/км }{ }^{2}\right)\end{array}$ & $\begin{array}{c}\text { Объем вносимых мине- } \\
\text { ральных удобрений, (кг/га) }\end{array}$ & $\begin{array}{c}\text { Объем сточных } \\
\text { вод, (тыс. м }\end{array} /$ год) \\
\hline 1 & чистое & $<40$ & $<10$ & $<0,5$ \\
\hline 2 & среднее & $40-80$ & $10-20$ & $0,5-2$ \\
\hline 3 & грязное & $80-160$ & $20-30$ & $2-4$ \\
\hline 4 & - & $160-240$ & $30-40$ & $4-8$ \\
\hline 5 & - & $>240$ & $>40$ & $>8$ \\
\hline
\end{tabular}

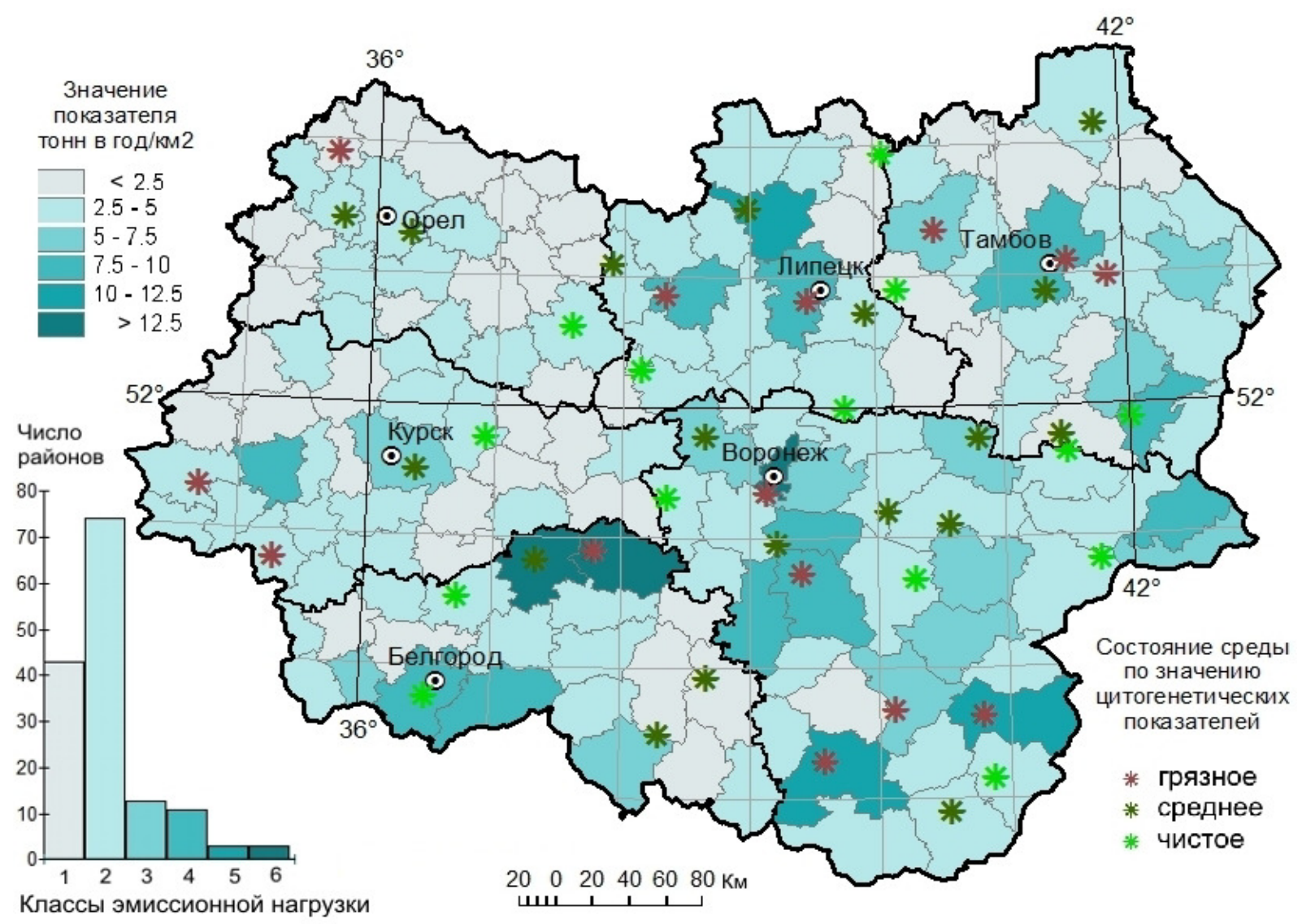

Puc. 2. Схема эмиссионной нагрузки на атмосферу на территории ЦЧР.

перерабатывающая промышленность. В целом, для Белгородской области суммарный объем загрязнения атмосферного воздуха от основных горнодобывающих и перерабатывающих предприятий (ОЭМК,
Стойленский и Лебединский ГОК, заводы «Белгородский цемент», «Осколцемент», «Стройматериалы» Белгород) составляет 86,5 тонн в год, что соответствует 9,1 \% валового объема веществ от передвиж- 
ных и стационарных источников, загрязняющих атмосферу [21]. К пятому классу опасности с выбросами в атмосферу от 10 до 12,5 тонн в год/км² относятся Калачеевский и Россошанский районы Воронежской, а также Лебедянский район Липецкой областей. Но это не связано с горнодобывающими предприятиями (за исключением Россошанского района).

На рис. 3 приведен анализ распределений значений состояния окружающей среды по цитогенетическим показателям относительно эмиссионной нагрузки на атмосферу. Эмиссионная нагрузка, отложенная по оси абсцисс, классифицирована на три класса с значениями менее $3,7,3,7-7,7$ и более 7,4 т в год/км² в соответствии с числом градаций состояния ОС по цитогенетическим показателям. Цвет символа определяет состояние окружающей среды: зеленый - чистое, темнозеленый - среднее, коричневый - грязное. Размер символа и расположенное рядом числовое значение соответствуют числу отобранных проб, попадающих в районы с определенной эмиссионной нагрузкой.

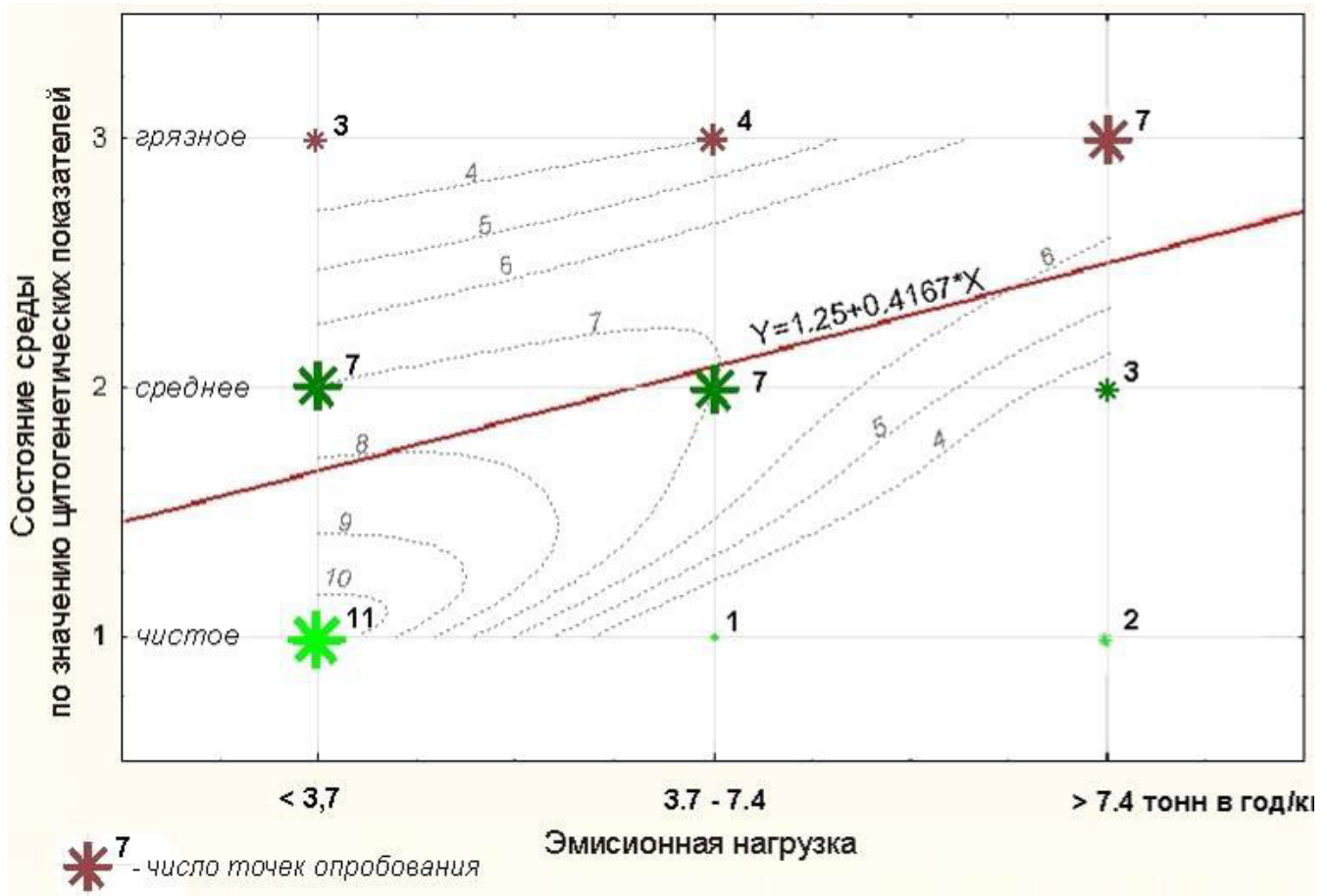

Puc. 3. Распределение значений состояния окружающей среды по цитогенетическим показателям относительно эмиссионной нагрузки на атмосферу.

Наибольшие количества проб (7 и 11) соответствуют совпадающим уровням параметров атмосфера-состояние ОС: минимальное - чистое, среднее среднее, большое - грязное. Изолинии подчеркивают общий тренд ухудшения состояния ОС по значениям цитогенетических показателей в соответствии с ростом количества атмосферных выбросов. Значениями изолиний является число точек опробования цитогенетических показателей, соответствующее определенному состоянию природной среды и определенной эмиссионной нагрузке.

В группу с чистым состоянием природной среды по цитогенетическим показателям и эмиссионной нагрузкой менее 3,7 т в год на км² (11 точек опробования) попадают Прохоровский район Белгородской области, Бобровский, Нижнедевицкий, Новохоперский, Петропавловский и Терновский районы Воронежской области, Щигровский район Курской области, Усманский и Чаплыгинский районы Липецкой, Ливенский район Орловской и Петровский район Тамбовской области.

В группу со средним состоянием природной среды по цитогенетическим показателям и эмиссионной нагрузкой от 3,7 до 7,4 т в год на км ${ }^{2}$ (7 точек опробования) попадают Аннинский, Семилукский, Эртильский районы Воронежской, Курский район, Измалковский и Грязинский районы Липецкой, Орловский район Орловской областей. В группу с грязным состоянием природной среды по цитогенетическим показателям и эмиссионной нагрузкой более 7,4 т в год на км² (7 точек опробования) попадают Старооскольский район Белгородской Калачеевский, Лискинский и Россошанский районы Воронежской области, Елецкий и Липецкий районы Липецкой области, Тамбовский район Тамбовской области. Необходимо учитывать, что цитогенетическое опробование проведено по 45 из 147 районов ЦЧР.

На рис. 4 приведена схема плотности линейной эрозии для территории ЦЧР на основе суммарной длины фактически установленных проявлений, приходящихся на единицу площади. Зафиксирована тесная связь проявлений данного типа с геологогеоморфологическими районами территории ЦЧР и ее неотектоническим положением. Для сопоставления 


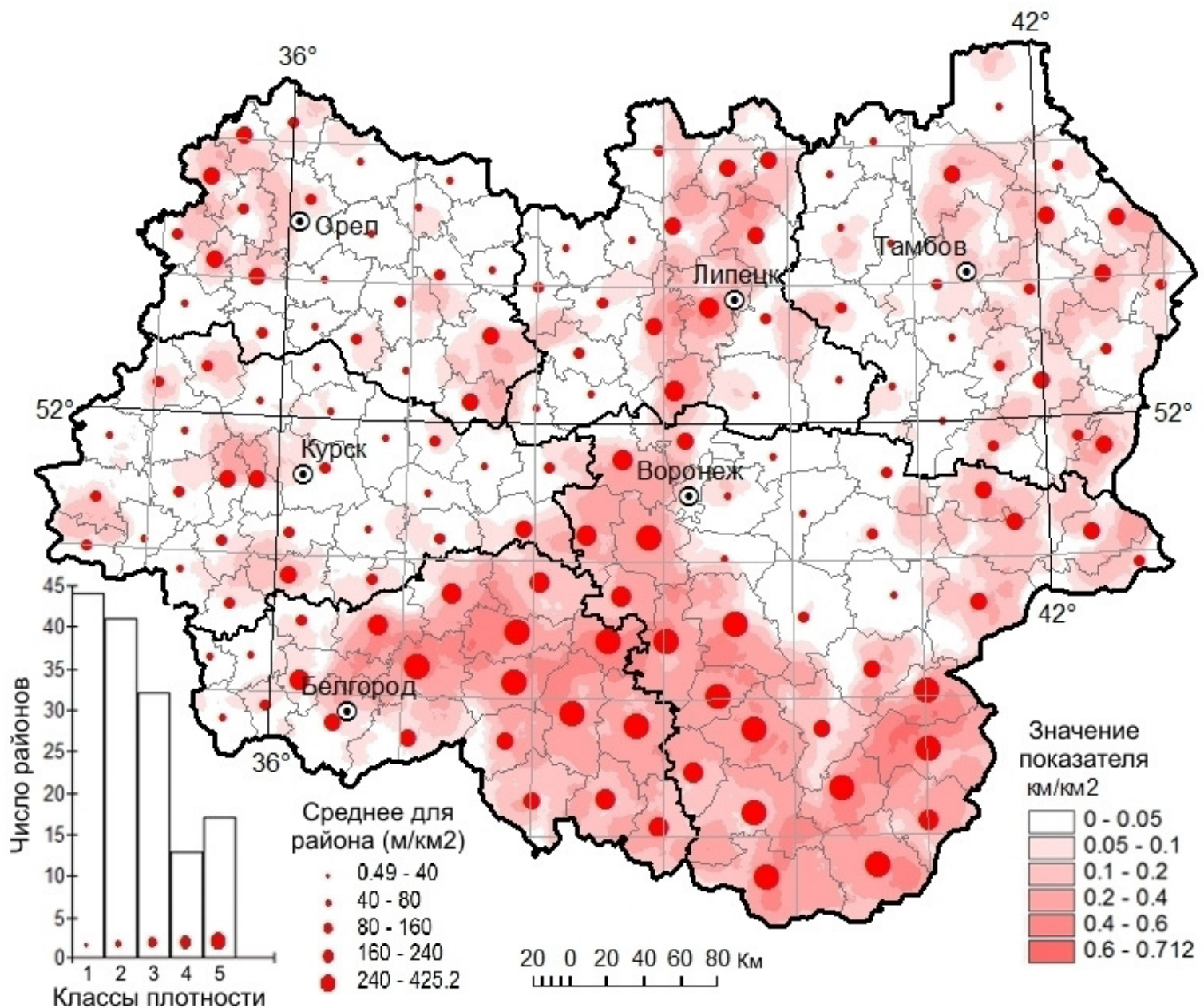

Puc. 4. Схема плотности линейной эрозии ЦЧР.

проявлений плотности линейной эрозии с другими техногенными показателями усреднены данные для административных районов и вынесены на схему в виде градуированных точечных символов. Для них отмечается снижение абсолютных значений показателя плотности с 712 до 425 м/км². Наибольшая плотность линейной эрозии в абсолютных значениях и пораженные ею площади отмечаются для юговосточной части Среднерусской равнины (большая часть Белгородской и южная часть Воронежской областей). Отчетливо проявлена субмеридиональная полоса повышенной плотности линейной эрозии западнее линии г.г. Воронеж-Липецк шириной от 35 до 45 км.

При анализе техногенной нагрузки на земельные ресурсы на территории ЦЧР, представленной на рис. 5 , отмечается, что более $60 \%$ территории распахивается, подвергаясь сельскохозяйственной обработке и химизации. Максимальные площади распаханности в Липецкой (66,2 \%), Курской (65,2 \%) и Тамбовской областях $(64,9 \%)$. Значения этого показателя по отдельным районам изменяются от 44,3 \% для Острогожского района Воронежской области и в 14-ти районах, из которых половина в Орловской области, превышают 70 \% площади. Максимальная распаханность в 76,4 \% отмечается для Корсаковского района Ор- ловской области.

Наибольшие объемы вносимых минеральных удобрений - до 10 кг/га отмечаются для 29 районов ЦЧР, из которых 14 относятся к Курской и 9 к Тамбовской областям. Минимальные значения - 2 кг/га вносятся в почву в Солнцевском районе Курской области. Более 40 кг/га минеральных удобрений используется в Белгородском, Губкинском, Шебекинском, Красногвардейском районах Белгородской и в Глушковском районе Курской областей. При этом корреляционные связи между рассмотренными двумя показателями техногенной нагрузки на почвы отсутствуют $-32,5 \%$, что видно из табл. 6. Очевидно, что в данном случае необходим учет направленности в использовании земель сельскохозяйственного назначения, типов почвенного покрова, климатических и других факторов.

На схеме техногенной нагрузки на поверхностные водные ресурсы на территории ЦЧР, как видно на рис. 6, максимальные значения соответствуют областным территориальным образованиям Белгорода и Липецка, Губкинскому, Старооскольскому, Павловскому горнопромышленным районам. Для Борисоглебского, Елецкого, Лебедянского, Ливенского и Ржаксинского районов высокие значения данного 


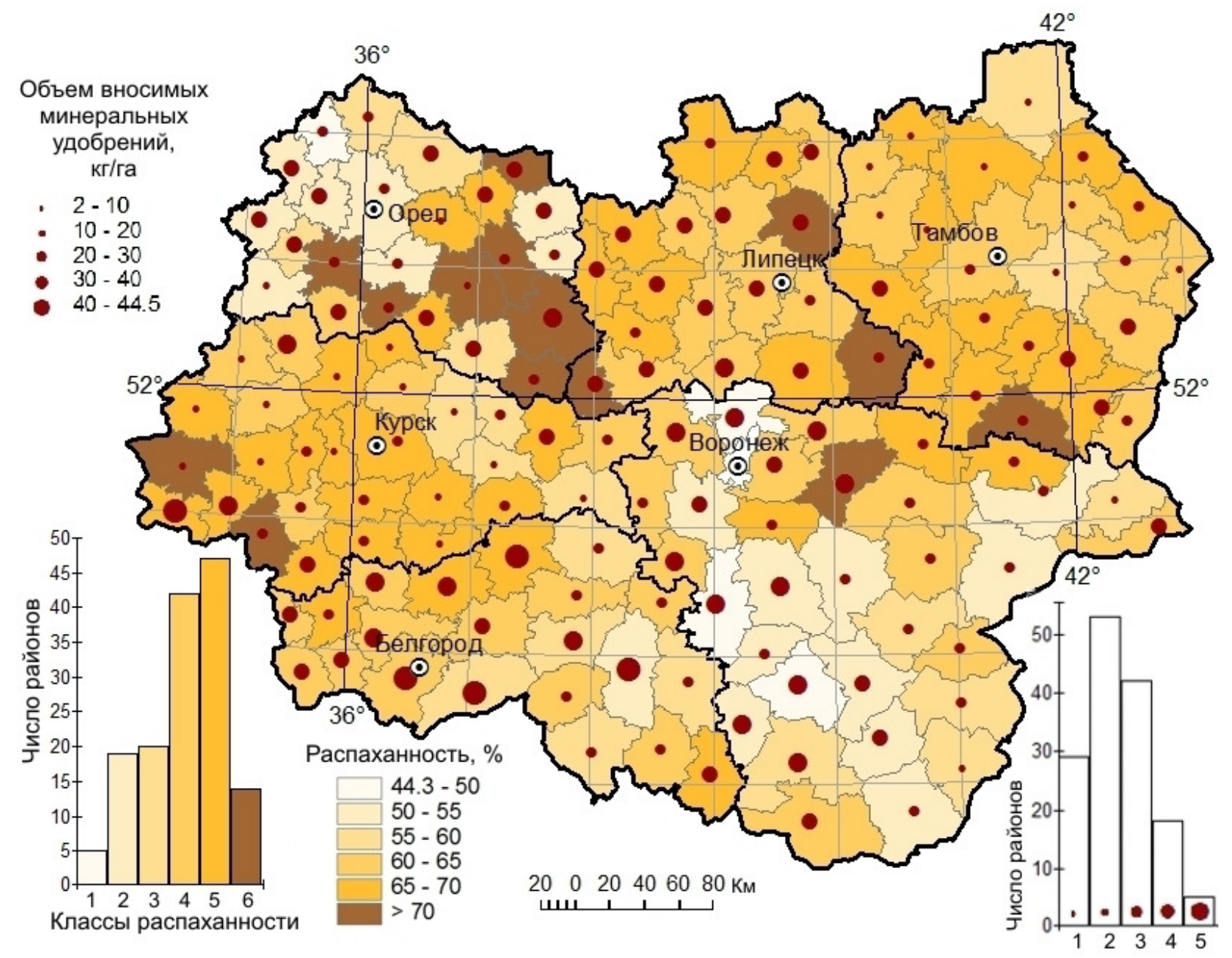

Puc. 5. Схема техногенной нагрузки на земельные ресурсы ЦЧР.

Таблица 6

Коэффициенты корреляции между индикаторными показателями

состояния окружающей среды для опорных районов ЦЧР

\begin{tabular}{|c|c|c|c|c|c|c|c|c|c|c|c|c|}
\hline \multirow[b]{3}{*}{ 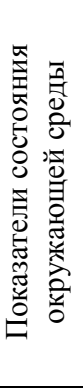 } & \multirow[b]{3}{*}{ 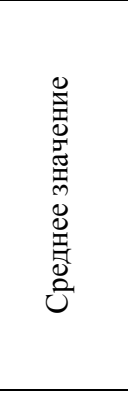 } & \multirow[b]{3}{*}{ 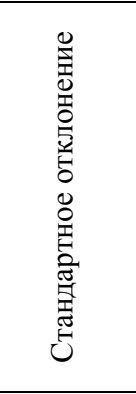 } & \multicolumn{10}{|c|}{ Показатели состояния окружающей среды } \\
\hline & & & 1 & 2 & 3 & 4 & 5 & 6 & 7 & 8 & 9 & 10 \\
\hline & & & 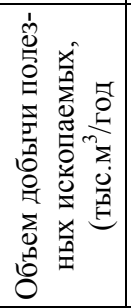 & 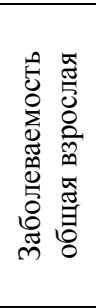 & 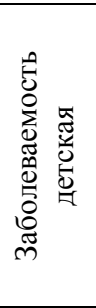 & 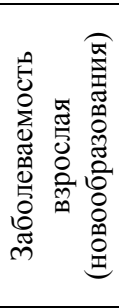 & 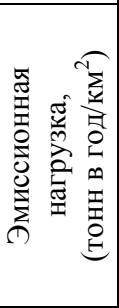 & 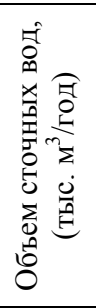 & 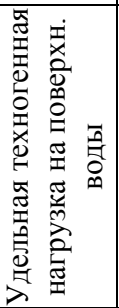 & 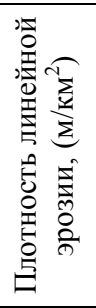 & 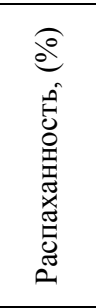 & 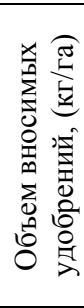 \\
\hline 1 & 2025,59 & 4464,602 & 1 & 0,381 & 0,301 & 0,264 & $\mathbf{0 , 8 3 6}$ & 0,575 & 0,541 & 0,432 & 0,271 & $\mathbf{0 , 6 3 3}$ \\
\hline 2 & 1238,37 & 270,734 & 0,381 & 1 & 0,832 & 0,498 & 0,462 & 0,448 & 0,240 & 0,122 & 0,237 & 0,351 \\
\hline 3 & 1556,97 & 337,511 & 0,301 & $\mathbf{0 , 8 3 2}$ & 1 & 0,257 & 0,550 & 0,689 & 0,545 & 0,144 & 0,075 & 0,396 \\
\hline 4 & 39,19 & 9,305 & 0,264 & 0,498 & 0,257 & 1 & 0,375 & $-0,067$ & $-0,207$ & 0,696 & 0,053 & 0,353 \\
\hline 5 & 4,88 & 3,665 & 0,836 & 0,462 & 0,550 & 0,375 & 1 & 0,685 & 0,612 & 0,648 & $-0,043$ & 0,726 \\
\hline 6 & 238 & 2,963 & 0,575 & 0,448 & 0,689 & $-0,067$ & 0,685 & 1 & 0,948 & 0,148 & 0,087 & 0,491 \\
\hline 7 & 16,56 & 19,966 & 0,541 & 0,240 & 0,545 & $-0,207$ & 0,612 & 0,948 & 1 & 0,110 & 0,010 & 0,514 \\
\hline 8 & 87,54 & 70,645 & 0,432 & 0,122 & 0,144 & 0,696 & 0,648 & 0,148 & 0,110 & 1 & $-0,069$ & 0,616 \\
\hline 9 & 63,50 & 5,904 & 0,271 & 0,237 & 0,075 & 0,053 & $-0,043$ & 0,087 & 0,010 & $-0,069$ & 1 & 0,325 \\
\hline 10 & 22,81 & 11,501 & 0,633 & 0,351 & 0,396 & 0,353 & 0,726 & 0,492 & 0,514 & 0,617 & 0,325 & 1 \\
\hline
\end{tabular}




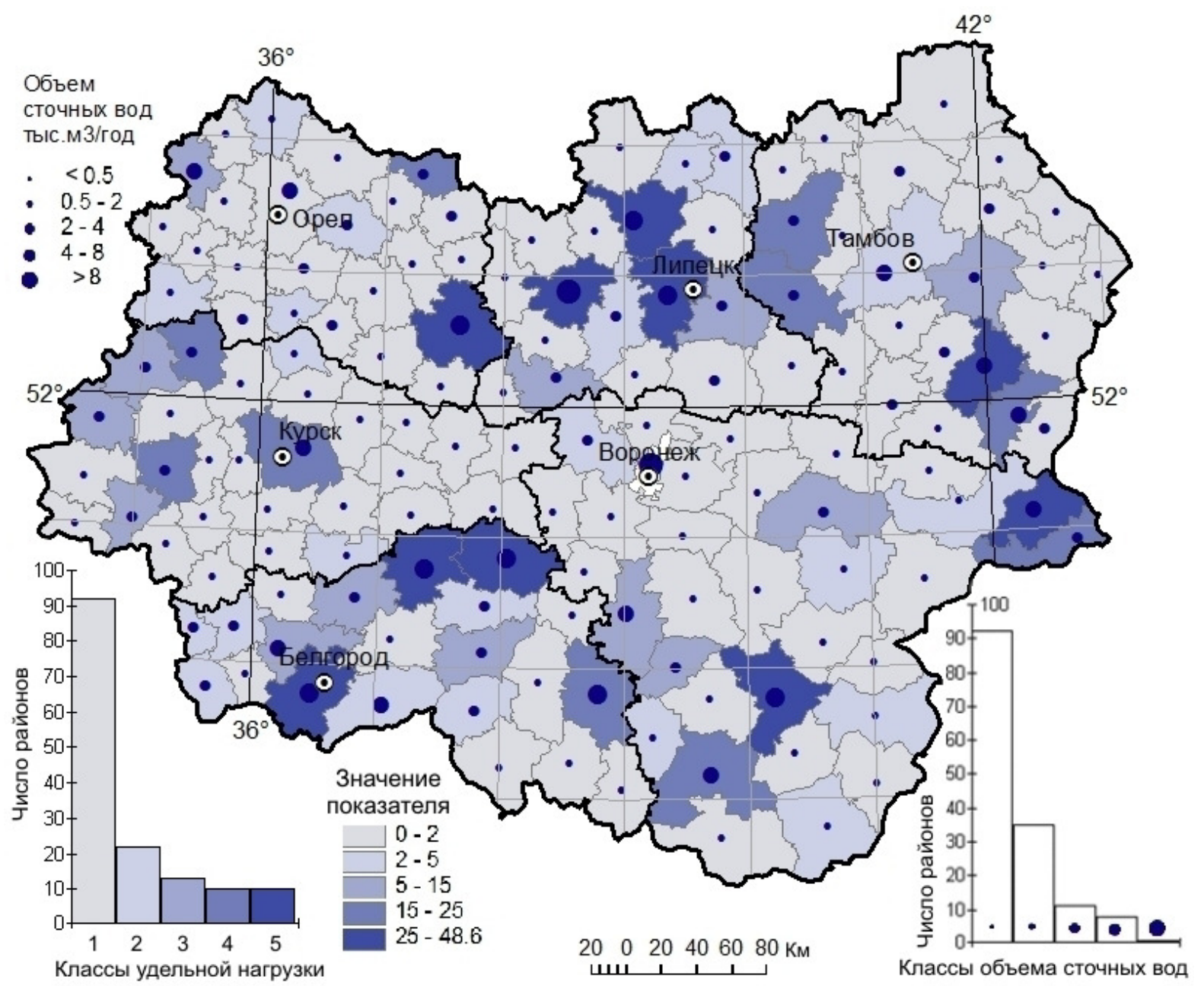

Puc. 6. Схема техногенной нагрузки на поверхностные водные ресурсы ЦЧР.

показателя связаны с предприятиями строительных материалов и сельскохозяйственной переработки. Значения этого показателя зависят и рассчитаны исходя из общего запаса поверхностных вод для конкретной территории. Их изменение для территории ЦЧР - от 0 до 48,6.

Объем сбрасываемых загрязненных сточных вод в поверхностные водоемы для изучаемой территории изменяется от нулевых значений, при отсутствии в районе крупных предприятий-загрязнителей ОС, до 8,67 тыс. м ${ }^{3} /$ год для Елецкого района Липецкой области. Далее в порядке убывания со значениями более 4 тыс. м $^{3}$ год следуют Лебедянский $(7,89)$, Липецкий $(7,62)$, Губкинский $(5,64)$, Ливенский $(5,32)$, Белгородский $(5,09)$, Старооскольский $(4,78)$, Павловский $(4,63)$, Алексеевский $(4,2)$ районы, относящиеся к 4 и 5-му классам по объемам сбрасываемых загрязненных сточных вод.

Результаты корреляционного анализа между индикаторными показателями состояния окружающей среды, для опорных районов ЦЧР, в обобщенном виде представлены в табл. 6. Жирным шрифтом выделены коэффициенты парной корреляции со значениями более $60 \%$.
На основании анализа табл. 6, для показателя 1 (объем добычи полезных ископаемых) отмечается устойчивая связь с эмиссионной нагрузкой на атмосферу (объем выбросов загрязняющих веществ от передвижных и стационарных источников, показатель 5) - 83,6 \%. В свою очередь, эмиссионная нагрузка на атмосферу, как один из основных техногенных факторов, связана на уровне 68,5 \% с объемом сбрасываемых загрязненных сточных вод в поверхностные водоемы (показатель 6) и на уровне 64,8 \% с плотностью проявлений линейной эрозии (показатель 8). Тесная связь (94,8 \%) объема сбрасываемых сточных вод и удельной техногенной нагрузки на поверхностные воды (показатель 7) связана с «вложенностью» данных показателей, когда один из них рассчитывается с учетом другого.

Связь общей взрослой и детской заболеваемости $(83,2$ \%) зависит, прежде всего, от плотности населения, хотя детская заболеваемость на уровне устойчивых средних связей $(68,9$ \%) также коррелируется с объемом сбрасываемых загрязненных сточных вод. Привлекает внимание связь $(69,6$ \%) онкозаболеваний и линейной эрозии. Последняя, являясь проявлением современных геодинамических процессов в зоне ги- 
пергенеза, тесно связана с неотектоническим режимом территории и с неотектоническими разрывными нарушениями. Возможная связь геотектоники и онкозаболеваний освещалась в печати [22, 23].

В целом, связь заболеваемости населения с горной промышленностью, на уровне районных показателей, ожидаема для отдельных крупных градообразующих предприятий. Результаты её влияния на окружающую среду зависят от ряда условий: в первую очередь от производительности предприятий, выражением которой является объем перерабатываемого сырья, класса опасности полезного ископаемого, условий его добычи и переработки, близости населенных пунктов и сопутствующих факторов. Для мелких предприятий, при обобщении данных до уровня административных районов, их влияние на заболеваемость населения не является определяющим. Так для Воронежской области к наиболее крупным предприятиям горнодобывающего и перерабатывающего комплекса, загрязняющим атмосферу и связанным с добычей и переработкой строительного камня из гранита, относится ОАО «Павловскгранит» [24]. Однако, его вклад, совместно с расположенным в Павловском районе Воронежской области сахарным заводом, не превышает 2 \% в областном масштабе.

На основе данных по техногенным показателям и табл. 6 построен график зависимости эмиссионной нагрузки на атмосферу от объема добычи полезных ископаемых для опорных районов ЦЧР, представленный на рис. 7.

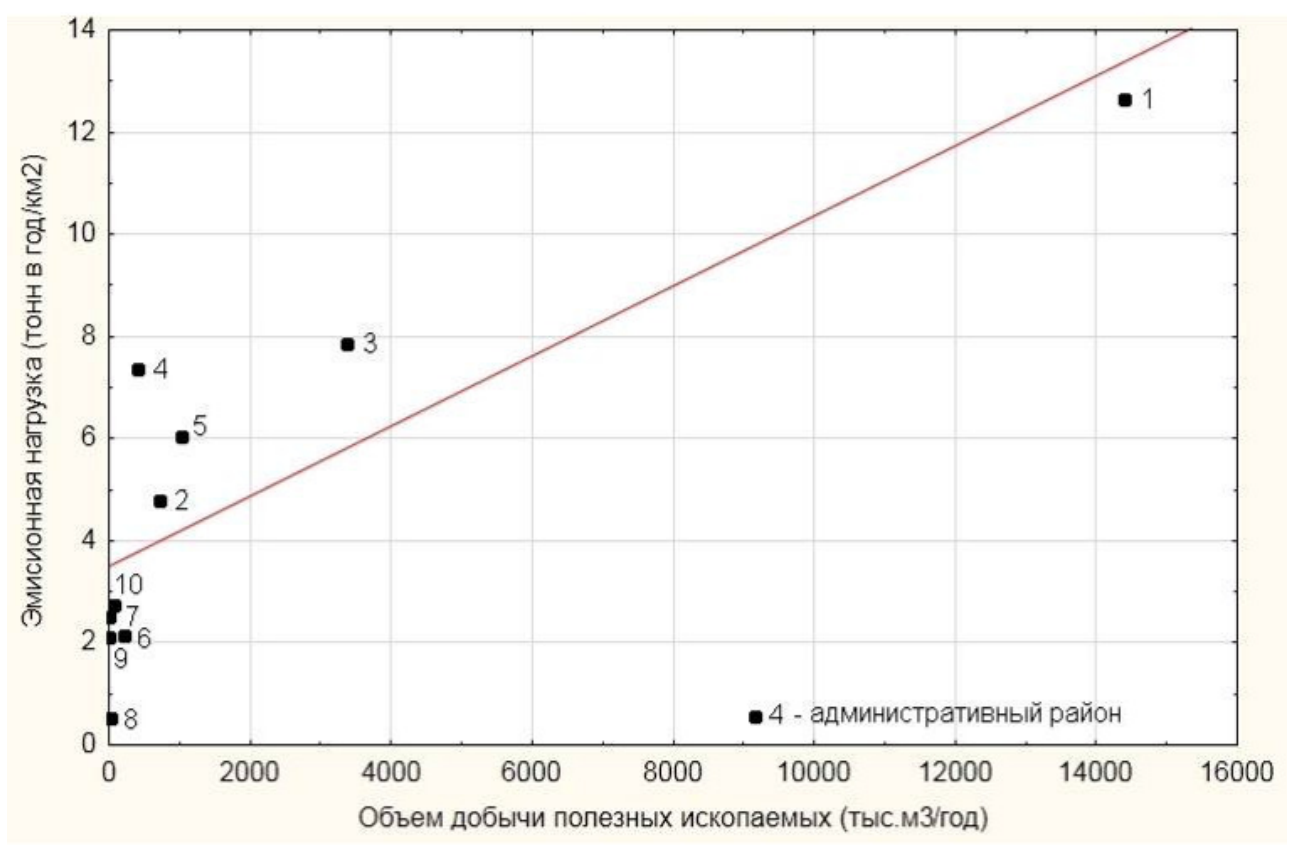

Рис. 7. График зависимости эмиссионной нагрузки на атмосферу от объема добычи полезных ископаемых для опорных районов ЦЧР. Номера опорных районов:

$1-$ Губкинский, 2 - Задонский,

3 - Елецкий,

4 - Семилукский,

5 - Павловский,

6 - Советский,

7 - Моршанский,

8 - Краснозоренский,

9 - Тимский,

10 -Волоконовский.

Уравнение линейной регрессии, построенное для пары показателей объем добычи / эмиссионная нагрузка имеет вид $\mathrm{Y}=3,487+0,0007 * \mathrm{X}$. Данный график пересекает ось $\mathrm{X}$ в точке 3,487 (тонн в год на $\mathrm{Kм}^{2}$ ), что на основании исходных данных, может быть принято за средний «фоновый» уровень эмиссионной нагрузки при отсутствии горнодобывающей промышленности. При планировании роста добычи полезных ископаемых, на основе вышеприведенного уравнения, возможно получение прироста эмиссионных выбросов. Данное увеличение соответствует второму слагаемому в уравнении регрессии $0,0007 *$ X. На основе полученных по результатам настоящих работ для всех административных районов ЦЧР фактических значений эмиссионной нагрузки, а также рассчитанному приросту эмиссионных выбросов, в зависимости от предполагаемых объемов добычи полезных ископаемых, были получены итоговые расчетные значения данного показателя.

Кроме этого, по опорным районам построены регрессионные зависимости для техногенных показате- лей, связанных с поверхностными сточными водами, от объема добычи полезных ископаемы. Так для объема сбрасываемых загрязненных сточных вод в поверхностные водоемы получено уравнение $\mathrm{Y}=1,6043+0,0004 * \mathrm{X}$ (рис. 8a). Для удельной техногенной нагрузки на водные ресурсы это уравнение $\mathrm{Y}=11,6659+0,0024 * \mathrm{X}$ (рис. 8б). В обоих случаях значением аргумента является объем добычи полезных ископаемых, а значением функции - соответствующий техногенный показатель.

На основании вышеприведенных уравнений в табл. 7 приведены расчетные значения отдельных техногенных показателей в зависимости от предполагаемого объема добычи полезных ископаемых для отдельных районов дальнесрочного освоения. Для показателей здоровья населения данные расчеты не проводились, т.к. это является задачей специальных исследований и требует более широкого набора исходных показателей.

C учетом вышеперечисленных приоритетных критериев, характеризующих напряженность медико- 

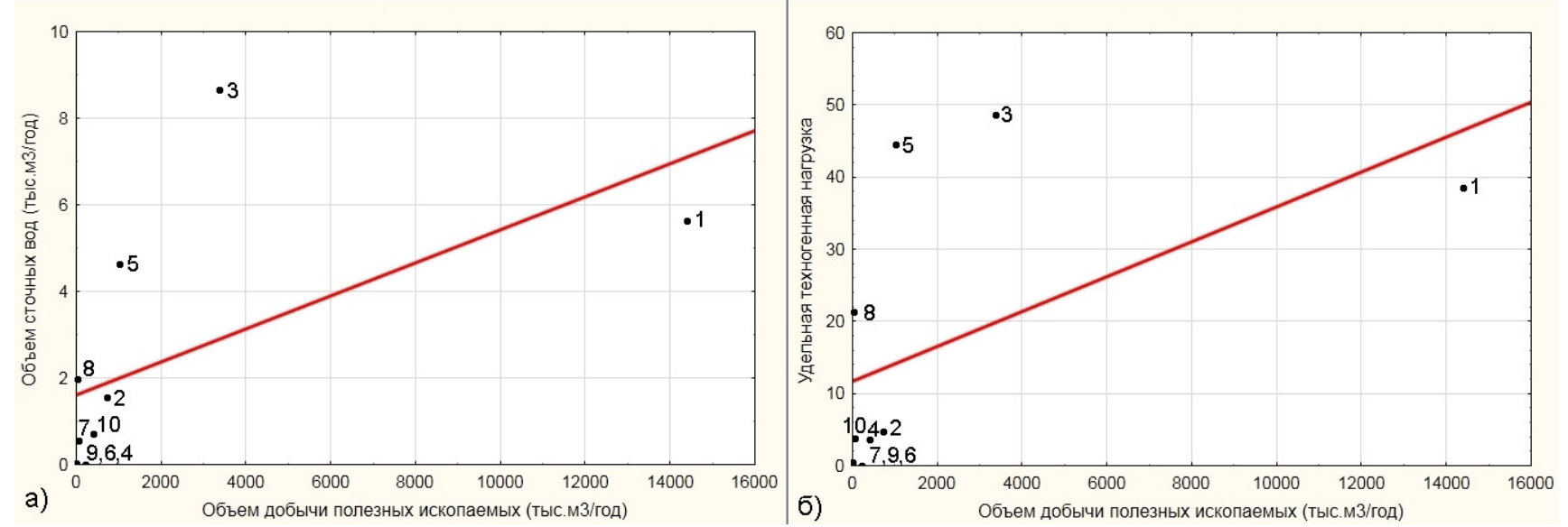

Puc. 8. Графики зависимости: а - объема сточных вод, б - удельной техногенной нагрузки на водные ресурсы от объема добычи полезных ископаемых для опорных районов ЦЧР.

Таблица 7

Изменение показателей техногенной нагрузки в районах дальнесрочного освоения

\begin{tabular}{|c|c|c|c|c|c|c|c|c|c|c|}
\hline \multirow{2}{*}{$\begin{array}{c}\text { Администра- } \\
\text { тивный } \\
\text { район }\end{array}$} & \multirow{2}{*}{$\begin{array}{c}\text { Предполагае- } \\
\text { мый объем } \\
\text { добычи } \\
\text { (тыс.м3/год) }\end{array}$} & \multicolumn{3}{|c|}{$\begin{array}{c}\text { Эмиссионная нагрузка } \\
(\text { тонн в год/км²) }\end{array}$} & \multicolumn{3}{|c|}{$\begin{array}{c}\text { Объем сточных вод } \\
\left(\text { тыс. } \text { м }^{3} / \text { год) }\right.\end{array}$} & \multicolumn{3}{|c|}{$\begin{array}{c}\text { Удельная техногенная } \\
\text { нагрузка } \\
\end{array}$} \\
\hline & & факт. & $\triangle^{*}$ & расч. & факт. & $\triangle$ & расч. & факт. & $\triangle$ & расч. \\
\hline Новохоперский & 1500 & 3,12 & 1,05 & 4,17 & 0,14 & 0,6 & 0,74 & 1,1 & 3,6 & 4,7 \\
\hline Рассказовский & 2000 & 2,89 & 1,4 & 4,29 & 12,87 & 0,8 & 13,67 & 6,5 & 4,8 & 11,3 \\
\hline Лев-Толстовский & 6000 & 4,21 & 4,2 & 8,41 & 2,12 & 2,4 & 4,52 & 21,4 & 14,4 & 35,8 \\
\hline Добровский & 4000 & 1,56 & 2,8 & 4,36 & 0,98 & 1,6 & 2,40 & 22,6 & 9,6 & 32,2 \\
\hline Суджанский & 1000 & 4,56 & 0,7 & 5,26 & 0,56 & 0,4 & 0,96 & 16 & 2,4 & 18,4 \\
\hline Черемисиновский & 50 & 2,02 & 0,035 & 2,055 & 0,78 & 0,02 & 0,8 & 18,5 & 0,12 & 18,62 \\
\hline Советский & 50 & 2,15 & 0,035 & 2,185 & 0 & 0,02 & 0,02 & 26,7 & 0,12 & 26,82 \\
\hline Верхнемамонский & 6014 & 3,17 & 4,21 & 7,38 & 0 & 2,41 & 2,41 & 22,5 & 14,43 & 36,93 \\
\hline
\end{tabular}

Примечание: * $\triangle$ - приращение показателя в зависимости от предполагаемого объема добычи полезных ископаемых.

экологической ситуации для каждого административного района и крупных населенных пунктов получены значения интегрального рейтинга напряженности медико-экологической ситуации. Эта рейтинговая оценка приведена к пяти классам бальной шкалы, от низкого до высокого, представленных в за рамочном оформлении схемы интегрального рейтинга напряженности медико-экологической ситуации. Данная цветовая палитра рейтинговой оценки использована в модели оптимального использования минеральносырьевой базы в условиях интенсивного воздействия антропогенных факторов (см. рис. 1) и в таблицах степени антропогенной нагрузки в виде фонового цвета для названий районов. Для таблицы степени антропогенной нагрузки в зонах дальнесрочного освоения дано двойное цветовое отображение напряженности медико-экологической ситуации: фактическое - на настоящий момент и расчетное - с учетом объемов предполагаемой добычи полезных ископаемых. При этом если по одному из трех расчетных показателей техногенной нагрузки только один переходит в новый класс (см. табл. 4, 5), интегральная рейтинговая оценка района остается неизменной. Если по одному из трех расчетных показателей техногенной нагрузки два и более показателей переходят в новый класс, интегральная рейтинговая оценка района повышается на одну ступень.

Исходя из предполагаемых объемов добычи полезных ископаемых в зонах дальнесрочного освоения сохраняется интегральная рейтинговая оценка для Рассказовского, Суджанского, Черемисиновского и Советского районов. Для Новохоперского, Лев-Толстовского, Добровского и Верхнемамонского районов предполагается повышение медико-экологической оценки на одну ступень (табл. 8).

Для Новохоперского района Еланской зоны дальнесрочного освоения, исходя из предполагаемого объема добычи 1500 тыс. м $^{3} /$ год, на один класс увеличиваются показатели объема сточных вод (с 0,14 до 0,74 тыс. $\mathrm{m}^{3} /$ год) и удельной техногенной нагрузки (с 1,1 до 4,7), что переводит его интегральный рейтинг напряженности медико-экологической ситуации с пониженного на средний.

Для Лев-Толстовского и Добровского районов Северо-Липецкой зоны дальнесрочного освоения при предполагаемых объемах добычи в 6000 и 4000 тыс. 
Таблица 8

Изменение показателей интегрального рейтинга напряженности медико-экологической ситуации

\begin{tabular}{|c|c|c|c|c|}
\hline \multirow{2}{*}{$\begin{array}{c}\text { Зоны } \\
\text { освоения }\end{array}$} & \multirow{2}{*}{$\begin{array}{c}\text { Административный } \\
\text { район }\end{array}$} & \multirow{2}{*}{$\begin{array}{c}\text { Предполагаемый } \\
\text { объем добычи } \\
\text { (тыс. м³/год) }\end{array}$} & \multicolumn{2}{|c|}{$\begin{array}{c}\text { Интегральный рейтинг напряженности } \\
\text { медико-экологической ситуации }\end{array}$} \\
\hline & & & фактический & расчетный \\
\hline Еланьская & Новохоперский & 1500 & пониженный & средний \\
\hline Рассказовская & Рассказовский & 2000 & пониженный & пониженный \\
\hline \multirow{2}{*}{ Северо-Липецкая } & Лев-Толстовский & 6000 & средний & повышенный \\
\hline & Добровский & 4000 & средний & повышенный \\
\hline \multirow{2}{*}{ Щигровская } & Черемисиновский & 50 & средний & средний \\
\hline & Советский & 50 & средний & средний \\
\hline Южно-Воронежская & Верхнемамонский & 6014 & пониженный & средний \\
\hline
\end{tabular}

$\mathrm{m}^{3} /$ год перейдут в более высокий класс все три расчетных показателя техногенной нагрузки. Для них соответственно возрастают значения эмиссионной нагрузки с 4,21 до 8,41 т в год/км² и с 1,56 до 4,36 т в год/км², объема сточных вод с 2,12 до 4,52 тыс. $\mathrm{m}^{3} /$ год и с 0,90 до 2,58 тыс. $\mathrm{m}^{3} /$ год, удельной техногенной нагрузки с 21,4 до 35,8 и с 22,6 до 32,2. Это переводит интегральный рейтинг напряженности медико-экологической ситуации данных районов со среднего на повышенный.

Для Верхнемамонского района Южно-Воронежской зоны дальнесрочного освоения предполагается увеличение добычи полезных ископаемых на 6014 тыс. ${ }^{3} /$ год, особенно в связи с освоением месторождений мамонской песчано-каолиновой толщи [25]. Это также переведёт в более высокий класс все три расчетных показателя техногенной нагрузки с увеличением значений объема выбросов загрязняющих веществ в атмосферу с более чем в два раза с 3,17 до 7,38 т в год/км ${ }^{2}$, появление такого техногенного фактора как сточные воды с 0 до 2,41 тыс. $\mathrm{m}^{3} /$ год и рост удельной техногенной нагрузки на водные ресурсы с 22,5 до 36,93. При данных объемах добычи полезных ископаемых медико-экологический рейтинг территории понизится на одну ступень до среднего.

\section{Выводы}

Построенная модель включает 16 геолого-экономических зон, 7 из них (Старо-Оскольская, Данковская Северо-Западно-Воронежская, Липецкая, Железногорская, Елецкая, Павловская) относятся к зонам стабильного освоения, 4 (Щигровская, Северо-Липецкая, Рассказовская и Южно-Воронежская) - дальнесрочного освоения, и рекомендованы в качестве будущих центров экономического роста, 5 - (Чернянская, Дмитровская, Юго-Восточно-Воронежская, Белгородско-Шебекинская и Еланьская) - к зонам с неопределенными перспективами. В предлагаемой модели учтены известные запасы, а также прогнозные ресурсы минерального сырья, возможности воспроизводства и расширения МСБ, обеспеченность агропромышленного комплекса ЦЧР и страны с учетом введения в эксплуатацию нового для ЦЧР минерального сырья. К нему относятся стратегические для страны медно-никелевые руды, титан-циркониевые россыпи, каолины, а также обычно связанные с ними неметаллические полезные ископаемые.

Для ряда административных районов, в которых предполагается развитие горнодобывающих предприятий, определены объемы и виды добываемого сырья, подсчитана его стоимость. По этим параметрам даны прогноз загрязнения окружающей среды по отдельным техногенным показателям и итоговая комплексная экологическая оценка. Такой подход к обоснованию центров экономического роста на основе добычи и передела минерального сырья с учетом изменения экологических параметров окружающей среды является инновационным при освоении МСБ страны. При этом прогноз изменения экологического состояния ландшафтов выполнен с использованием наработок для действующих горных предприятий региона.

Модель может быть использована при рациональном планировании мероприятий в области недропользования на основе информации о МСБ региона, его инфраструктуре, сведений по минерально-экономическим районам региона и характеристике техногенных показателей состояния окружающей среды. Информативность и универсальность представленной модели даст возможность оптимального подхода к экологическому и экономическому освоению природных ресурсов и выпуска на их основе конкурентоспособной товарной продукции. Это разрешит проблему привлечения необходимых инвестиций в производство и тем самым сделает возможным развитие промышленности, но не только местной, но и в масштабах всей страны.

Использование модели позволит:

а) выработать оптимальные пути воспроизводства и развития МСБ региона с обеспечением полезными ископаемыми предприятий региона и страны в целом;

б) дать оценку последствий воздействия антропогенных факторов на природную среду;

в) рекомендовать создание центров экономического роста на базе разработки и передела различных видов минерального сырья с очередностью их освоения.

Исследование проведено при финансовой поддержке РФФИ, проект №17-05-00569. 


\section{ЛИТЕРАТУРА}

1. Природные ресурсы ЦЧЭР, перспективы их использования и охрана. - Воронеж: Изд-во Воронеж. 1985. $-156 \mathrm{c.}$

2. Минерально-сырьевая база неметаллических полезных ископаемых ЦЧР и рациональное её использование. Статья 1 . Состояние минерально-сырьевой базы неметаллов / А. Д. Савко [и др.] // Вестник Воронеж. гос. ун-та. Сер. Геология. - 2018. № 3. - С. 50-65.

3. Савко, А. Д. Керамические глины Центрально-Черноземного района / А. Д. Савко, А. В. Крайнов. - Тр. науч.-исслед. ин-та геологии Воронеж. ун-та. - Вып.88. - Воронеж. - 2015. $109 \mathrm{c}$.

4. Крайнов, А. В. Минерально-сырьевая база тугоплавких и огнеупорных глин Центрально-Черноземного района и перспективы её развития / А. В. Крайнов, Д. А. Дмитриев // Вестник Воронеж. гос. ун-та. Сер. Геология. - 2017. - №4. - С. 134 137.

5. Андреенков, В. В. Естественные отделочные и облицовочные материалы из осадочных пород северо-востока Воронежской антеклизы / В. В. Андреенков, А. Д Савко // Тр. науч.исслед. ин-та геологии Воронеж. ун-та. - Вып. 15. - Воронеж, 2003. $-94 \mathrm{c}$

6. Савко, А. Д. Огнеупорные глины и каолины Воронежской антеклизы / А. Д. Савко // Генезис и ресурсы каолинов и огнеупорных глин. - М.: Наука. - 1990. - С.35-47

7. Дмитриев, Д. А. Сантонские отложения Правобережья среднего течения реки Дон / Д. А. Дмитриев, А. Д. Савко, А. В Жабин // Тр. науч.-исслед. ин-та геологии Воронеж. ун-та. Вып. 21. - Воронеж, 2004. - 104 с.

8. Литология и полезные ископаемые сантона центральной части КМА / А. Д. Савко [и др.] - Тр. науч.-исслед. ин-та геологии Воронеж. ун-та. - Вып. 55. - 2009. - 108 с.

9. Горюшкин, В. В. Бентонитовые глины юго-востока Центрально-Черноземного района / В. В. Горюшкин, А. Д. Савко Тр. науч.-исслед. ин-та геологии Воронеж. ун-та. - Вып. 37. 2006. - $176 \mathrm{c}$

10. Савко, А. Д. Фосфориты Центрально-Черноземного района России / А. Д. Савко, В. И. Беляев, С. В. Мануковский. - Воронеж : Изд-во Воронеж. гос. ун-та, 1994. - 183 с.

11. Савко, А. Д. Алмазы и их спутники из осадочного чехла Воронежской антеклизы / А. Д. Савко, Л. Т. Шевырёв, В. В. Ильяш - Тр. науч.-исслед. ин-та геологии Воронеж. ун-та. Вып. 47. - Воронеж, 2007. - 127 с.

12. Савко, А. Д. Ассоциации минералов-индикаторов алмазоносности в осадочном чехле Воронежской антеклизы / А. Д Савко, Л. Т. Шевырев, В. В. Ильяш. - В сб. Проблемы алмазной геологии и некоторые проблемы их решения. АК «АЛРОСА» (ЗАО); отв. редакторы Н. Н. Зинчук, А. Д. Савко. - Воронеж, 2001. - C.423-433.

13. http://www.vestnik.vsu.ru/pdf/heologia/2018/04/2018-04pic1.pdf

14. Разработка модели оптимального использования минерально-сырьевой базы в условиях интенсивного воздействия антропогенных факторов (на примере ЦЧР) / А. Д. Савко [и др.] - Отчет о НИР. - Воронежский государственный университет. - Воронеж. - 2012. - 141 с.

15. Стафеев, К. Г. Опыт стандартизации условных обозначений геолого-экономических карт, создаваемых в технологии ГИС / К. Г. Стафеев // Разведка и охрана недр. - 2005. - № 7. C. $42-45$.

16. Дмитриев, Д. А. Геолого-экономическая дифференциация Центрально-Черноземного региона / Д. А. Дмитриев // Вестник Воронеж. гос.ун-та. Сер. Геология. - 2013. - № 1. - С. 148-154.

17. Минерально-сырьевой потенциал недр Российской Федерации. Том 1: Прогнозно-металлогенический анализ. - СПб.: Изд-во ВСЕГЕИ, 2009, - 224 с.

18. Минерально-сырьевой потенциал недр Российской Федерации. Том 2. Минерально-сырьевой и стоимостный анализ. СПб.: Изд-во ВСЕГЕИ, 2009, - 492 с.

19. Богатство недр России. Минерально-сырьевой и стоимостный анализ. - СПб.: Изд-во ВСЕГЕИ, 2008. - 483 с.

20. Методическое руководство по составлению и подготовке к изданию листов Государственной геологической карты Российской Федерации масштаба 1: 1000000 (третьего поколения). - СПб.: ВСЕГЕИ, 2009. -288 с.

21. Доклад об экологической ситуации в Белгородской области в 2010 году. - Белгород, 2011. - 187 с.

22. Доклад о государственном надзоре и контроле за использованием природных ресурсов и состоянием окружающей среды Воронежской области в 2005 году / В. И. Ступин [и др.]. - Воронеж: ГУП ВО «Воронежская областная типография - издательство им. Е.А. Болховитинова», 2006. - 112 с.

23. Экология Центрального Черноземья: учеб. пособие / Д. В. Муха [и др.] - Курск: Изд-во КГСХА, 2002. - 191 с.

24. Протасова Н. А. Редкие и рассеянные элементы в почвах Центрального Черноземья / Н. А. Протасова, А. П. Щербаков, М. Т. Копаева. - Воронеж: Изд-во Воронеж. ун-та, 1992. - 168 c.

25. Савко, А. Д. Литология и полезные ископаемые мамонской песчано-каолиновой толщи / А. Д. Савко, С. В. Мануковский, Л. Т. Шевырев - Тр. науч.-исслед. ин-та геологии Воронеж. ун-та. - Вып.53. - Воронеж, 2008. - 112 с.

Voronezh State University

Dmitriev D. A., associate professor of the Historical Geology and Paleontology Department, Candidate of Geological and Mineralogical Sciences.E-mail: dmitgeol@yandex.ru Savko A. D., Head of the Historical Geology and Paleontology Department, doctor of the Geological and Mineralogical Sciences, Professor, Celebrated Geologist of Russia E-mail:savko@geol.vsu.ru; Tel.: +7(473)2208660 Kurolap S. A., Doctor of Geographical Sciences, Professor, Dean of the Faculty of Geography, Geoecology and Tourism, Head of the Department of Geoecology and Environmental Monitoring

E-mail: skurolap@mail.ru,.Tel.:+7(473)2665654

Kalaev V. N., Doctor of biological Sciences, professor of the Genetic, Cytology and Bioengineering department

E-mail:Dr_Huixs@mail.ru; Tel.: +74732208876

Ivanov D. A., Associate professor of the Historical Geology and Paleontology Department, Candidate of Geological and Mineralogical Sciences. E-mail: ivanov@geol.vsu.ru 